NBER WORKING PAPER SERIES

HEALTH EFFECTS OF ECONOMIC CRISES

Christopher J. Ruhm

Working Paper 21604

http://www.nber.org/papers/w21604

\author{
NATIONAL BUREAU OF ECONOMIC RESEARCH \\ 1050 Massachusetts Avenue \\ Cambridge, MA 02138 \\ October 2015
}

I thank participants of the Workshop on Consequences of the Economic Crisis on Health and Health Care Systems held at UNED, Madrid, Spain and seminar participants at the Erasmus University Health Economics Group for helpful comments. The views expressed herein are those of the author and do not necessarily reflect the views of the National Bureau of Economic Research.

NBER working papers are circulated for discussion and comment purposes. They have not been peerreviewed or been subject to the review by the NBER Board of Directors that accompanies official NBER publications.

(C) 2015 by Christopher J. Ruhm. All rights reserved. Short sections of text, not to exceed two paragraphs, may be quoted without explicit permission provided that full credit, including $\odot$ notice, is given to the source. 
Health Effects of Economic Crises

Christopher J. Ruhm

NBER Working Paper No. 21604

October 2015

JEL No. E32,I1,I12,I18,J68

\begin{abstract}
This analysis summarizes prior research and uses national, state and county level data from the United States from 1976-2013 to examine whether the mortality effects of economic crises differ in kind from those of the more typical fluctuations. The tentative conclusion is that economic crises affect mortality rates (and presumably other measures of health) in the same way as less severe downturns: namely, they lead to improvements in physical health. The effects of severe national recessions in the United States, appear to have a beneficial effect on mortality that is roughly twice as strong as that predicted due to the elevated unemployment rates alone while the higher predicted rate of suicides during typical periods of economic weakness is approximately offset during severe recessions. No consistent pattern is obtained for more localized economic crises occurring at the state level - some estimates suggest larger protective mortality effects while others indicate offsetting deleterious consequences.
\end{abstract}

Christopher J. Ruhm

Frank Batten School of

Leadership and Public Policy

University of Virginia

235 McCormick Rd.

P.O. Box 400893

Charlottesville, VA 22904-4893

and NBER

ruhm@virginia.edu 
Research from a variety of countries and time periods conducted over the last 15 years shows that mortality is procyclical - rising when economic conditions improve and falling when they deteriorate. Following Ruhm (2000), most of these studies utilize longitudinal data and panel techniques to control for many confounding factors, including time-invariant area-specific determinants and characteristics that vary over time in a uniform manner across locations. The question addressed here is whether the mortality effects of economic crises differ in kind from those of the more typical fluctuations that have been previously examined. A particular challenge is that, to borrow from Leo Tolstoy, while all “regular” business cycles are (somewhat) alike, each economic crisis may differ in its own way. One reason is that crises could potentially involve the partial or complete collapse of economic or social institutions, including those affecting health and mortality. Operationalizing the analysis of crises is therefore likely to be somewhat idiosyncratic and the results obtained should be viewed as exploratory. The empirical portion of this investigation considers whether severe national and localized recessions in the United States have mortality effects that go beyond, fall short of, or move in the opposite direction from those anticipated based on more typical macroeconomic fluctuations.

Drawing on prior research and the empirical results below, the tentative conclusion is that economic crises affect mortality rates (and presumably other measures of health) in the same direction as less severe downturns - leading to improvements in physical health. Moreover, the beneficial effects of severe national recessions in the United States appear to be roughly twice as strong as those predicted due to higher unemployment rates alone and the increase suicide rates usually associated with worsening economic conditions is roughly offset by the severe recession effect. However, no consistent pattern of effects is obtained for economic crises occurring at the state level.

\section{What We Know So Far}


The conventional wisdom, prior to the turn of the $21^{\text {st }}$ century, was that health deteriorates when the economy weakens and improves when it strengthens. ${ }^{1}$ An important adherent of this view, Harvey Brenner conducted a series of studies (e.g. Brenner 1971, 1979, 1987) using lengthy national time-series, showing that recessions and other sources of economic instability increased overall mortality and deaths from many causes, as well as morbidity, alcoholism and admissions to mental hospitals. This research was been widely criticized on technical grounds (e.g. Kasl, 1979; Gravelle, et al., 1981; Wagstaff, 1985) and studies addressing the concerns (e.g. Forbes \& McGregor, 1984; McAvinchey, 1988), obtained results that were sensitive to the choice of countries, time periods and proxies for health. ${ }^{2}$ Some subsequent investigations continued to use time-series methods (e.g. Joyce \& Mocan, 1993; Laporte, 2004; Gerdtham \& Johannesson 2005; Tapia Granados \& Ionides, 2008), albeit with more sophisticated approaches designed to correct problems with earlier studies. However, these methods have not provided robust results, most probably because any lengthy time-series may yield biased estimates due to omitted factors that are spuriously correlated with economic conditions and health.

As an alternative, most researchers now use panel data methods containing information on health or mortality outcomes for multiple locations over several time periods. Consider a panel of aggregate state-level with mortality as the outcome of interest. A typical estimation equation is:

$$
\ln \left(M_{\mathrm{kst}}\right)=\alpha_{\mathrm{ks}}+X_{\mathrm{st}} \beta+U_{\mathrm{st}} \gamma+\lambda_{\mathrm{kt}}+T_{\mathrm{kst}}+\varepsilon_{\mathrm{kst}}
$$

where $M_{\mathrm{kst}}$ is the mortality rate from source $k$ in state $s$ at year $t, U$ is the proxy for macroeconomic conditions, $X$ a vector of state characteristics, $\alpha$ a state fixed-effect, $\lambda$ a general time effect, $T$ a statespecific time trend, $\varepsilon$ is the error term, and $\hat{\gamma}$ provides the estimated macroeconomic effect of interest.

Mortality rates are often studied because they represent the most severe negative health outcome, are well measured (although there can be errors in the assigned cause of death) and diagnosis

\footnotetext{
${ }^{1}$ This was true even though analyses undertaken as early as the 1920s (Ogburn \& Thomas, 1922; Thomas, 1927), uncovered positive relationships between economic activity, total mortality and several specific causes of death.

${ }^{2}$ See Ruhm (2012) for an in-depth discussion.
} 
generally does not require access to the medical system. ${ }^{3}$ Unemployment rates are the most common proxy for macroeconomic conditions but employment-to-population ratios, per capita GDP or similar variables are sometimes used. Supplementary regressors vary but often include measures of age, education and race/ethnicity. Some analyses add lags of the macroeconomic variables or use other methods to capture dynamics of the adjustment process.

In (1), the year effects $\left(\lambda_{\mathrm{kt}}\right)$ hold constant time-varying determinants that are national in scope (e.g. advances in widely used medical technologies or behavioral norms); the state fixed-effects $\left(\alpha_{\mathrm{ks}}\right)$ account for those that differ across states but are time-invariant (such as persistent lifestyle disparities between residents of Nevada and Utah) and the state-trends $\left(T_{s t}\right)$ control for some location-specific time-varying determinants. The macroeconomic impact is identified from within-location variations in mortality rates, relative to changes in other states and controlling for demographic characteristics and state-trends. This presents potential issues for examining the effects of economic crises, to which I return below. However, at this point, it is worth emphasizing that unemployment rates are included in (1) to proxy for macroeconomic conditions, and $\hat{\gamma}$ does not indicate the mortality effects of job loss or movements into unemployment. ${ }^{4}$

Investigations using the methods just described (or slight variations) and data from a variety of locations strongly indicate that total mortality and several important causes of death rise during expansions and fall in times of economic weakness. In Ruhm's (2000) analysis of state-level U.S. data from 1972 to 1991, a one percentage point increase in the state unemployment rate lowered predicted total mortality rates by $0.5 \%$ and motor vehicle and cardiovascular disease (CVD) deaths by 3.0\% and 0.5\%, respectively, with reductions also observed for fatalities from influenza/pneumonia, liver

\footnotetext{
${ }^{3}$ However, changes in non-life-threatening health conditions (e.g. arthritis) will not be accounted for. A few analyses (e.g. Ruhm, 2003 and Charles \& DeCicca, 2008) have used similar models to examine effects on morbidities.

${ }^{4}$ Thus, it is quite possible for macroeconomic downturns to be associated with improved health, even while rigorous previous research (e.g. Sullivan \& von Wachter, 2009) shows that job loss is associated with increases in individual mortality rates. Modrek et al. (2013) provides a comprehensive literature review that carefully distinguishes between the health effects of changes in macroeconomic conditions from those of individual unemployment.
} 
disease, non-vehicle accidents and homicides. By contrast, cancer mortality was unaffected and suicides were estimated to rise by $1.3 \%$. This last result suggests that physical and mental health move in opposite directions.

The procyclicality of total mortality has been confirmed using data for 16 German states from 1980-2000 (Neumayer, 2004), 50 Spanish provinces from 1980-1997 (Tapia Granados, 2005), 96 French depártments from 1982-2003 (Buchmueller, et al., 2007), 31 Mexican states from 1993-2004 (Gonzalez \& Quast, 2011), 10 Canadian provinces from 1977-2009 (Ariizumi \& Schirle, 2012), 23 OECD countries from 1960-1997 (Gerdtham \& Ruhm, 2006), and 8 Pacific-Asian nations from 19762003 (Lin, 2009). ${ }^{5}$ Motor vehicle and CVD fatalities exhibit similar patterns in almost all studies, with more variation for mortality from other causes. ${ }^{6}$

There is evidence that, at least in the U.S., mortality has become less procyclical in recent years. Using state-level data from 1978-2006, Stevens et al. (2011) find that a one percentage point increase in the unemployment rate predicted a $0.40 \%$ reduction in total mortality from 1978-1991, but a smaller 0.19\% decrease from 1978-2006. ${ }^{7}$ McInerney \& Mellor (2012) indicate that a one-point rise in joblessness lowered predicted mortality rates of seniors (65 and over) by 0.3\% during 1976-1991, but raised them 0.5\% from 1994-2008. Ruhm (2015) provides the most complete analysis of this issue. Using state-level data for 1977-2010, he estimates that total mortality shifted over time from strongly procyclical to being largely unrelated to macroeconomic conditions. These secular changes vary across causes, with deaths from CVD remaining as strongly procyclical at the end of the sample period as at the beginning of it, but with countercyclical patterns emerging for cancer mortality and external

\footnotetext{
${ }^{5}$ Economou et al. (2008) find that total mortality is negatively but insignificantly related to unemployment rates for $13 \mathrm{EU}$ countries from 1977-1996, and that the predicted effect reverses sign when controlling smoking, drinking, calorie consumption and pollution rates (suggesting that these may provide important mechanisms for some of the effects). ${ }^{6}$ Stuckler et al. (2009) obtain evidence from 26 EU countries for 1970-2007 of positive, negative and neutral relationships between unemployment rates and suicides, deaths from transport accidents, and total mortality. Their statistical methods focus on rates of changes in mortality and unemployment and so are not completely comparable to the other research discussed in this section.

${ }^{7}$ The estimated reduction rises to $0.33 \%$ over the $1978-2006$ period when using age-adjusted mortality rates.
} 
sources of death, especially for non-transport accidents. Finally, he demonstrates that reliable estimates are unlikely to be obtained when using relatively short (less than 15-year) analysis periods.

Health lifestyles provide a potential mechanism for the macroeconomic effects. There is considerable evidence that harmful behaviors - like heavy drinking and smoking - decrease in bad economic times, whereas health-enhancing activities such as exercise and social interactions increase (e.g. Ruhm \& Black, 2002; Ruhm, 2005; Gruber \& Frakes, 2006; Edwards, 2011; Xu, 2013). However, research for recent periods (e.g. Charles \& DiCicca, 2008; Arkes, 2007; Dávlos et al., 2012; Colman \& Dave, 2013) raises questions about some of these relationships or indicates that the patterns may have changed over time, although such results should be interpreted cautiously because the analysis periods are short (eight years or less).

\section{What We Don't Yet Know}

Despite a large and growing body of research examining how macroeconomic conditions affect health, we know surprisingly little about whether the patterns observed during "standard" economic fluctuations are reinforced, weakened or reversed in times of crises. To some degree, this may be because the basic estimation model, described by equation (1), is poorly formulated to answer this question. Two shortcomings are worth noting. First, the specification treats the macroeconomic proxy (usually unemployment rates) as being linearly related to the outcome (log mortality rates). For example, a one percentage point increase in the unemployment rate is assumed to have the same effect, but in the opposite direction, as a one point decrease, and the impact of it rising from $4 \%$ to $5 \%$ is constrained to be the same as a change from $10 \%$ to $11 \%$. Neither assumption is necessarily true and economic crises generally involve substantial increases in joblessness to unusually high rates. Second, the inclusion of year dummy variables in the basic model absorbs all effects that are national in scope, so that it is not possible to estimate how national recessions affect mortality. (The models are identified based on changes in state-level economic conditions.) Both issues will be at least partially addressed in 
the econometric analysis below. However, before turning to the original empirical work, I discuss what can be learned from prior investigations.

Some information may be gained by examining how estimates of macroeconomic effects obtained using standard panel data methods differ when analyzing samples that do and do not include severe downturns. While somewhat inconclusive, such investigations suggest that the mortality declines observed during times of general economic weakness do extend to periods of crisis. Spanish provincial unemployment rates during the 1980-1997 timespan examined by Tapia Granados (2005) varied between $7 \%$ and $24 \%$, with the latter constituting an economic crisis by almost any measure. His estimates indicate that a one percent point increase in the unemployment rate lowered total mortality by around $0.11 \%$. While this effect is smaller than in other countries (e.g. compared to the $0.3 \%$ to $0.5 \%$ change often estimated for the U.S.) Spanish unemployment rates were both high and variable (averaging 19.3\% with a standard deviation of 7.2 percentage points) so that, for example, a one standard deviation increase in unemployment lowers the predicted death rate by around 8\%. However, Tapia Granados did not explicitly test for nonlinearities in the effects during times of economic crisis.

Several studies examine periods that include or are centered on the Great Recession. van Gool \& Pearson's (2014) analysis of 34 OECD countries from 1997-2011 indicates that unemployment rates are negatively, but somewhat weakly, associated with overall mortality rates and deaths from several sources, with suicides varying in the opposite direction: a one point increase in unemployment predicts a $0.18 \%$ reduction in all-cause mortality. Drinking, smoking, and the expected use of several types of medical care also decline, although the estimates are often statistically insignificant. Toffolutti \& Suhcke (2014) uncover extremely large procyclical variations in total and most causes of mortality 
(with suicides again the exception) using data for $23 \mathrm{EU}$ countries from 2003-2010. ${ }^{8}$ Tekin et al. (2013) examine U.S. state-level data from 2005-2011 and find that unemployment rates are negatively associated with smoking, drinking and obesity, and positively correlated with exercise. However, the estimates are often small and imprecise (particularly when controlling for state-specific trends), leading them to conclude that there are at most weak relationships. An alternative interpretation is that the 7-year analysis period is too short to provide reliable estimates.

Ruhm (2015) examines how the unemployment rate coefficients vary during all 20-year periods occurring between 1976-2010. At first glance, the dramatic reduction over time in the procyclicality of mortality (the unemployment coefficient falls from a statistically significant -0.0043 for 1976-1995 to an insignificant -0.0010 for 1991-2010) might suggest weaker macroeconomic effects for analysis periods that include the Great Recession. However, this interpretation is probably incorrect because the magnitude of the estimated effects begin to attenuate long before the Great Recession and increase slightly during the last two 20-year periods (1990-2009 and 1991-2010), which include data from the Great Recession.

Researchers have also investigated the effects of economic crises other than the Great Recession. Fishback et al. (2007) used data for 114 cities from 1929-1940 to examine how the Great Depression (which lasted from 1929-1939 and was at its worst in 1932-1933) affected mortality and whether these impacts were buffered by spending on New Deal relief programs. Particularly relevant to this investigation is the evidence of procyclical variations in the overall non-infant death rate and in mortality from homicides, infectious and parasitic diseases, cancers, degenerative diseases and motor vehicle fatalities, with suicides again varying countercyclically. ${ }^{9}$ Similarly, Stuckler et al. (2012), using data for 36 U.S. states from 1929-1937, showed that worse state economies were associated with lower

\footnotetext{
${ }^{8} \mathrm{~A}$ one percentage point increase in unemployment is predicted to reduce total mortality by $2.6 \%-3.7 \%$. While these effects seem implausibly large, they note that extending the sample period to 1991-2010 reduces the predicted effect by more than two-thirds. This provides further evidence of the fragility of the estimates to the use of short analysis periods.

${ }^{9}$ They also find that New Deal relief programs reduced many types of mortality.
} 
rates of overall (detrended) mortality and deaths from many sources, although they believe these patterns oftren reflect factors other than macroeconomic conditions. Tapia Granados \& Roux (2009), using time-series methods for the U.S. from 1920-1940, examined how trend deviations in national mortality rates and life expectancy covary with annual macroeconomic conditions. They provide evidence that most causes of mortality fall and life expectancies rise (relative to trend) when economic conditions weaken, with suicides again a notable exception. An issue for all three studies is that mortality rates were falling sharply in the years prior to the start of the Great Depression; a failure to correctly adjust for preexisting trends could therefore lead to erroneous estimates.

Ásgeirsdóttir et al. (2014) examine health behaviors just before and after the 2008 Icelandic economic crisis. Since the crisis was sudden, severe and unanticipated, the estimates are unlikely to be biased by unobserved confounding factors or longer-term trends. ${ }^{10}$ They find that most behavioral responses to the crisis were health-enhancing, including reductions in smoking, indoor tanning and the consumption of alcohol, soft drinks and sweets at the same time that (beneficial) sleep and fish oil consumption increased. However, not all effects were positive as fruit and vegetable consumption also declined. Price changes provided an important mechanisms for the effects. The overall price index rose 27\% between, 2007 and 2009, while prices of (mostly imported) tobacco, alcohol, soft drinks, sweets, fruits and vegetables increased by $40 \%, 49 \%, 57 \%, 50 \%, 92 \%$ and $38 \%$, whereas those of (domestically produced) fish oil grew just $19 \% .^{11}$

The research just summarized suggests that the relationship between macroeconomic conditions and mortality observed during "typical" economic fluctuations is likely to persist to periods of crisis. However, this need not always occur. An important counter-example is Russia following the breakup of the Soviet Union. Brainerd \& Cutler (2005) note that life expectancy fell 6.6 years for

\footnotetext{
${ }^{10}$ According to Ásgeirsdóttir et al., Iceland's three largest banks had assets 14 times larger than GDP before the crisis. These three banks collapsed in October of 2008, leading to an economic crisis that resulted in widespread business bankruptcies, a quadrupling of the unemployment rate and a $36 \%$ fall in the exchange rate.

${ }^{11}$ A follow-up analysis by Ásgeirsdóttir et al. (2015), which added data from 2012, after Iceland's economy had substantially recovered, found that most of the unhealthy behaviors (smoking, binge drinking, soft drink and fast food consumption) remained below pre-crisis levels. A likely reason is that prices for these products remained relatively high.
} 
males and 3.3 years for females between 1989 and 1994, an enormous decrease. After examining possible causes, they attribute key importance to increases in drinking problems, brought on by falling alcohol prices, and the higher stress associated with the poor outlook for the future (although evidence for this is mostly indirect). ${ }^{12}$ Notice that price changes led (mostly) healthier behaviors during Iceland's economic collapse, whereas the opposite was true for Russia’s economic upheaval.

\section{Methods}

When using state level data, the basic estimation model was previously described, by equation (1), with the unemployment rate coefficient $(\hat{\gamma})$ providing the estimated macroeconomic effect. When counties are the unit of analysis, the basic model will be modified as:

$$
\ln \left(M_{\mathrm{kct}}\right)=\alpha_{\mathrm{kc}}+X_{\mathrm{ct}} \beta+U_{\mathrm{st}} \gamma+\lambda_{\mathrm{kt}}+T_{\mathrm{kct}}+\varepsilon_{\mathrm{kct}}
$$

with the $c$ subscript indicating the county. State, rather than county, unemployment rates are controlled for in (1') because Lindo (2015) identifies important spillover effects across sub-state areas, such that controlling for county-level conditions understates the macroeconomic effects. Conservative assessments of statistical significance will be provided by clustering robust standard errors by state rather than county. ${ }^{13}$

When using state-level data, the effects of national economic crises will be estimated from:

$$
\ln \left(M_{\mathrm{kst}}\right)=\alpha_{\mathrm{ks}}+X_{\mathrm{st}} \beta+U_{\mathrm{st}} \gamma+N_{\mathrm{t}} \delta+T_{\mathrm{kst}}+\varepsilon_{\mathrm{kst}}
$$

and the corresponding specification using county-level data is:

$$
\ln \left(M_{\mathrm{kct}}\right)=\alpha_{\mathrm{kc}}+X_{\mathrm{ct}} \beta+U_{\mathrm{st}} \gamma+N_{\mathrm{t}} \delta+T_{\mathrm{kct}}+\varepsilon_{\mathrm{kct}}
$$

where $N_{\mathrm{t}}$ is a dummy variable indicating whether the national economy is in severe recession in year $t$. $\hat{\delta}$ then indicates whether national crises have mortality effects beyond those expected due to the associated higher rates of unemployment; $\hat{\gamma}$ here shows the macroeconomic effect during non-crisis

\footnotetext{
${ }^{12}$ Other potential mechanisms they examined, and concluded were not of primary importance, were: breakdown of the medical care system, increases in smoking or obesity, worse diets or material deprivation.

${ }^{13}$ County-clustered standard errors are typically one-half to two-thirds the size of the state-clustered standard errors.
} 
periods. The year dummy variables ( $\left.\lambda_{\mathrm{kt}}\right)$ must be excluded from (2) and (2'), since they are perfectly collinear with $N$, raising the possibility omitted variables bias. However, I show below that results from the basic specification (equations (1) and (1')) are insensitive to the exclusion of the time-specific effects, so that this is unlikely to be a major issue.

The effects of state economic crises are estimated from:

$$
\ln \left(M_{\mathrm{kst}}\right)=\alpha_{\mathrm{ks}}+X_{\mathrm{st}} \beta+U_{\mathrm{st}} \gamma+S_{\mathrm{st}} \delta+\lambda_{\mathrm{kt}}+T_{\mathrm{st}}+\varepsilon_{\mathrm{kst}}
$$

when using state-level data and for county data from:

$$
\ln \left(M_{\mathrm{kct}}\right)=\alpha_{\mathrm{kc}}+X_{\mathrm{ct}} \beta+U_{\mathrm{st}} \gamma+S_{\mathrm{st}} \delta+\lambda_{\mathrm{kt}}+T_{\mathrm{ct}}+\varepsilon_{\mathrm{kct}},
$$

where $S_{\text {st }}$ is a dummy variable indicating whether state $s$ is in crisis during year $t$. Once again, we are most interested in $\hat{\delta}$, and also in $\hat{\gamma}$.

\section{Data}

Mortality data come from the Center for Disease Control and Prevention’s Compressed Mortality Files (CMF) which contain death certificate information for U.S. residents. Data prior to 1988 are publicly available; those from 1989-2013 were obtained by special agreement with the CDC. Population data (the denominator in the mortality rate calculations) come from the National Cancer Institute's Surveillance Epidemiology and End Results (SEER) program. ${ }^{14}$ The SEER data were also used to construct independent variables for the share of the state or county population who were female, black, other (nonblack) nonwhite, and aged <1, 1-19, 45-54, 55-64, 65-74, 75-84 and $\geq 85$ years old.

Annual average state unemployment rates, the proxy for macroeconomic conditions, were obtained from the U.S. Department of Labor's Local Area Unemployment Statistics (LAUS) Database

\footnotetext{
${ }^{14}$ Additional information on the CMF and SEER data are available at: www.cdc.gov/nchs/data_access/cmf.htm and http://www.seer.cancer.gov/data. The SEER data are designed to supply more accurate population estimates for intercensal years than standard census projections, and to adjust for population shifts in 2005, resulting from Hurricanes Katrina and Rita. Differences between the SEER and CMF population estimates are miniscule prior to 2000 but are sometimes reasonably large (up to 3\%) after 2003.
} 
(www.bls.gov/lau/lauov.htm) ${ }^{15}$ The 1976-2013 analysis period reflects the availability of consistent data on unemployment and mortality rates.

In addition to total annual death rates, cause-specific mortality was examined. This introduces complications. From 1976-1978, cause of death was categorized using the $8^{\text {th }}$ revision of the International Classification of Diseases (ICD-8 codes). ICD-9 codes were used between 1979 and 1998, and ICD-10 categories since 1999. Crosswalks have been established between ICD-8 and ICD-9 and between ICD-9 and ICD-10 coding systems; however, the correspondence is imperfect. These issues are typically minor when looking at broad causes of death (e.g. those from cardiovascular disease) but are important for many specific sources of mortality.

The National Center for Health Statistics has calculated "estimated comparability ratios" indicating the relative number of deaths in 1996 attributed to a specific cause using ICD-9 and ICD-10 classifications (Anderson, et al., 2001) and for 1976 using ICD-8 versus ICD-9 codes (Klebba \& Scott, 1980). When the estimated comparability ratios are close to one (i.e. a similar number of deaths are reported using either ICD system), issues of data comparability are likely to be minor and well captured by the inclusion of regression year fixed-effects. For example, the estimated comparability ratios are 1.013 and 1.003 for CVD and cancer fatalities, when using ICD-8 and ICD-9 codes, and 0.998 and 1.007 for ICD-9 and ICD-10 categories. The potential problems are greater for some numerically important causes of death, and for others that have been analyzed in previous research. ${ }^{16}$ For this reason, the analysis is restricted to major causes of death, which are likely to be comparable across ICD coding systems. Specifically, I decompose total mortality into that from diseases versus external causes and then break down diseases into cardiovascular (CVD), malignant neoplasms (cancer), and all other diseases. Similarly, important subcategories of external deaths - transport

\footnotetext{
${ }^{15}$ A consistent series on county level unemployment rates begins in 1990 and the Department of Labor cautions against using county level data prior to that time. As mentioned, county unemployment rates would probably not be appropriate for this analysis, even if a consistent data series were available, because of spillovers effects across economic regions.

${ }^{16}$ For instance, the ICD-10 to ICD-9 comparability ratios are $0.698,1.232$ and 1.554 for influenza/pneumonia, kidney disease (nephritis, nephrotic syndrome, nephrosis) and Alzheimer's disease.
} 
accidents, non-transport accidents, intentional self-harm (suicide), and homicide/legal intervention are separately considered.

The county data contain 118,326 observations from 3,142 counties. However, many counties are quite small. For example, the median population is less than 24,000 and the $25^{\text {th }}$ and $10^{\text {th }}$ percentiles are below 11,000 and 6,000 respectively. By contrast, county population at the $90^{\text {th }}$ percentile exceeds 160,000 . This implies that many counties contribute little to the national population and that weighting will be necessary if there is unaccounted for heterogeneity in effects by population size. Measurement error (which is a particular issue in fixed-effect models) is also likely to be especially problematic for small counties. I address these issues in two ways. First, I test the sensitivity of the results to weighting the data and focus most attention on the weighted estimates. Second, the sample for most county-level estimates will be restricted to "large" counties, defined as those with a population average 25,000 or more during the 1976-2013 analysis period. This restriction eliminates 52 percent of county-year observations (reducing the sample size to 57,097 ) but just $7 \%$ of the national population. ${ }^{17}$ I also show that similar total mortality estimates are obtained for all and large counties, when using weighted data.

Appendix Table A.1 details the ICD-8, ICD-9 and ICD-10 codes used to classify causes of death. Appendix Table A.2 shows sample averages for the mortality outcomes, state unemployment rates and state/county level demographic characteristics. The means are weighted by location-specific populations and are shown using state-level data, from the full sample of 3.142 counties and for the 1,515 "large” counties. As expected, given the big sample sizes, standard errors are quite small. Also, as anticipated, the variable averages computed using the samples of states and all counties are

\footnotetext{
${ }^{17}$ An additional benefit of the smaller sample sizes is that the computational time declines from approximately 70 to eight minutes per regression.
} 
similar. ${ }^{18}$ After weighting, large counties have $2 \%$ to $3 \%$ lower rates of most types of mortality, but similar demographic characteristics.

\section{Defining Economic Crises}

Examining whether the health effects of economic crises differ from those of more "normal" downturns requires arriving at a reasonable definition of the former. I operationalize this by considering relatively extreme negative macroeconomic events occurring either nationally or at the state level, although this treatment is certainly arguable since the identified national recessions or statelevel downturns fall short of a complete collapse of the economy.

The United States experienced five national recessions during the analysis period (see Table 1). The first two occurred within months of each other -January through July of 1980 and July of 1981 through November of 1982. Given the relatively brief interval separating them, I treat these as a single recession below. Together, they were lengthy, totaling 22 months, and deep: GDP declined 2.2\% in the first and $2.7 \%$ in the second; annual unemployment rate rose almost four percentage points from the preceding trough (from 5.8\% in 1979 to $9.7 \%$ in 1982). The next two recessions, in 1990/91 and 2001, were brief (8 months each) and relatively shallow, with GDP declines of $1.4 \%$ and $0.3 \%$ and unemployment rate increases of 2.2 and 2.0 percentage points. Finally, the “Great Recession”, beginning in December of 2007, was lengthy (18 months) and deep, with GDP falling more than 4\% and unemployment growing from $4.6 \%$ in 2007 to $9.6 \%$ in 2010 . The analysis below treats the combined 1980-82 recessions and the Great Recession of 2007-09 as “severe” and uses these to examine the effects of national economic crises. The 1990/91 and 2001 recessions are classified as “mild” and are not treated as national crises, although controls for them are sometimes included. Unemployment rates lag other measures of economic performance and often reach a maximum after recessions officially end. For instance, the annual unemployment rate was 5.8\% in 2008 and $9.3 \%$

\footnotetext{
${ }^{18}$ They are not exactly equal because there are 393 county-year observations (out of 118,807) where the SEER populations were not matched to the CMF mortality rates, and another 88 observations where some information on population ages were missing.
} 
in 2009, during the Great Recession, but peaked at $9.6 \%$ in $2010 .{ }^{19}$ Given this, most of the analysis will use a "broad" definition whereby severe recession are defined to begin in the first year when the economy was in recession for at least six months - using official dates determined by the National Bureau of Economic Research (NBER) - and to continue through the year of the peak annual unemployment rates. By this definition, severe recession years included 1980-83 and 2008-2010, and mild recessions occurred during 1991-1993 and 2001-2003. ${ }^{20}$ I examined whether the results were sensitive to this dating scheme by estimating specifications using "narrow” definitions restricted to formal recession years according to the NBER (e.g. 1980-82 and 2008-09 for severe recessions).

Table 2, which shows (population-weighted) average state unemployment rates during recession and non-recession years, provides further justification for focusing on severe recessions. Using the broad definition, state unemployment rates were 2.3 percentage points higher during severe recessions than in other years (8.4\% versus $6.1 \%)$ and under the narrower definition they were 1.6 points greater. Conversely, joblessness barely increased during mild recessions using the broad definition (6.3\% versus 6.0\%), and rates were actually slightly lower in these periods when using the narrow definition.

State-level economic crises are even harder to define and so three alternative classifications are considered. Two of these focus on of high unemployment, relative to the state average. This is operationalized by considering the unemployment rate ratio (UN ratio), defined as the (annual) unemployment rate divided by the average (annual) state unemployment rate from 1976 through 2013. Crisis 1 is a dummy variable set to one if UN Ratio exceeds 1.377 , which is the $90^{\text {th }}$ percentile of population-weighted UN Ratio. Crisis 2 indicates more severe crises, and equals one if the UN Ratio is greater than 1.541, corresponding to the $95^{\text {th }}$ percentile. Crisis 3 considers both the UN Ratio and

\footnotetext{
${ }^{19}$ The peak monthly unemployment rate was $10.0 \%$ in October of 2009 (www.bls.gov/data/), four months after the formal end of the recession.

${ }^{20}$ The annual unemployment rate was actually slightly higher in 1982 than 1983 (9.7\% vs. 9.6\%); however, since these are so similar, 1983 is also included in the broad definition of that severe recession.
} 
absolute level of unemployment. Specifically, this dichotomous variable is set to one if the UN Ratio is above the $90^{\text {th }}$ percentile $(>1.377)$ and the annual unemployment rate exceeds $9.3 \%$, which is the $90^{\text {th }}$ percentile for all (population-weighted) state-year observations.

Table 3 provides summary information on these three variables. By construction, Crisis 1 and Crisis 2 are set to one for around $10 \%$ and 5\% of state-year observations; Crisis 3 equals one in around $7 \%$ of (population-weighted) cases. Unemployment rates average $10.2 \%$ to $11.5 \%$ during crisis periods (compared to around 6\% at other times) and are 57\% to 67\% above state averages. Unemployment rates and ratios are higher for Crisis 2 than Crisis 1, by definition, but the differences are not huge (10.9\% versus $10.2 \%$ and 1.67 versus 1.57$)$. Since Crisis 3 also conditions on absolute unemployment rates, the high (11.5\%) average rate when this variable equals one is unsurprising; however, unemployment ratios are also quite elevated.

\section{Economic Crises and Total Mortality: Estimates Using National Data}

Figure 1 provides a first indication the relationship macroeconomic conditions and total mortality, showing national annual values, detrended (using a linear trend) and standardized to have a mean of zero and a standard deviation of one. In this and later figures, the vertical dotted lines show official starting and ending dates of recessions (the narrow definition), with the 1980 and 1981/82 recessions combined. These results are illustrative only, since they do not control for potential confounding factors.

The figure suggests the inverse relationship between unemployment and mortality rates, that has been obtained in previous research. ${ }^{21}$ Two aspects are noteworthy. First, the mortality declines appear to be more pronounced during the severe than mild recessions. Second, unemployment rates typically peak after the recessions officially, as discussed, and mortality rates usually reach a trough near the end of them.

\footnotetext{
${ }^{21}$ Regressing detrended standardized mortality on the corresponding unemployment rate yields an unemployment rate coefficient of -0.453 with a robust standard error of 0.122 .
} 
Table 4 provides an econometric investigation of these relationships, and a first indication of whether the effects of national crises go beyond those expected due to the associated higher rates of unemployment. The dependent variable in each regression except model 6 is the natural log of the total mortality rate. In addition to unemployment rates, all models include a time trend constructed to have a value of zero in 1976 and one in 2013. Column (1) shows that a one-percentage point rise in unemployment predicts a $0.5 \%$ reduction in total mortality. The time trend coefficient of -0.087 of implies a ceteris paribus $8.3 \%$ secular decline in mortality between the beginning and end of the analysis period.

Model (2) adds a control for severe recessions to model, using the broad definition. Doing so attenuates the unemployment rate coefficient by $60 \%$, so that a one-point increase is predicted to reduce mortality by $0.3 \%$ during typical periods; however, there is an additional $1.4 \%$ decrease in deaths expected during severe recessions. Model (3) shows that the severe recession effect is virtually the same when using the narrow definition (based on official NBER timing) and model (4) shows that it is modestly attenuated when also controlling for mild recessions. ${ }^{22}$ Column (5) indicates that the protective effect of national economic crises was greater during the Great Recession than for the somewhat less traumatic, but still severe twin recessions occurring of the early 1980s. This is consistent with a dose-response relationship where larger mortality reductions occur when the severity of the national economic crisis deepens.

The dependent variable in model (6) is the level, rather than natural log, of the total death rate. Unemployment rates are again inversely related with mortality, with an additional protective effect observed during severe recessions. Since the total mortality rate is 846.5 per 100,000 individuals, a 2.42 predicted fall per one point increase in unemployment and an additional 11.82 decrease during severe recessions correspond to $0.3 \%$ and $1.4 \%$ reductions, respectively. These are essentially identical

\footnotetext{
${ }^{22}$ The mild recession coefficient in model (4) is positive and significant ( 0.0104 with a standard error of 0.0051$)$.
} 
to the effects obtained from the corresponding specification (model 2) using log mortality rates as the outcome.

\section{Panel Data Estimates}

\section{$\underline{7.1 \text { "Standard” Models, Without Economic Crisis Variables }}$}

Table 5 uses the methods described by equations (1) and (1') to examine the predicted effect of within-location changes in unemployment rates on (the log of) total mortality. These estimates correspond to those used in most previous research, except for the inclusion of more recent data, and do not contain additional controls for periods of economic crises. The top panel shows results using state level data; the middle and lower panels display corresponding findings for samples consisting of all counties and counties with populations averaging more than 25,000. Models (1) and (2) use unweighted data; observations are weighted by location-specific average populations in models (3) and (4). All models control for location-fixed effects, population characteristics and time-trends, as well as state unemployment rates. Year dummy variables also included in columns (2) and (4).

Using state level data, all specifications indicate that a one-percentage point increase in the unemployment rate correlates with around a $0.3 \%$ reduction in total mortality. Estimates using countylevel data reveal somewhat larger effects - typically around a $0.4 \%$ decrease - and more sensitivity to the use of sample weights, as expected if the macroeconomic effects differ between small (mostly rural) and larger counties. ${ }^{23}$ For this reason, weighted results are focused upon below. With weighting, virtually identical estimates are obtained for the all-county and large county samples, and the estimates are not sensitive to the inclusion of year dummy variables. The latter is important since time effects will be excluded from models examining effects of national economic crises, and suggests that such estimates are unlikely to be seriously biased by omitted time-specific factors.

\footnotetext{
${ }^{23}$ Standard errors are virtually the same as when using state-level data, probably because the robust standard errors are clustered at the state level.
} 
I next consider how the macroeconomic effects vary over time by estimating equation (1) or (1') for sub-periods of the data. Specifically, Figure 2 shows the unemployment coefficients where (log) total mortality is the outcome, for all available 15-year periods (i.e. the earliest window is 19761990 and the latest is 1999-2013). If the reductions in mortality predicted by higher unemployment rates were occurred only during “typical” business cycle fluctuations, and not during severe national crises, we would expect the negative predicted effects of higher unemployment on mortality to be reduced or eliminated for analysis windows including the beginning or end of the sample period, since these included the severe twin recessions of the early 1980s and the Great Recession of 2007-2009. Instead, we observe almost the opposite pattern. The unemployment coefficient (robust standard error) is $-0.0037(0.0007)$ for $1976-1990$, increases in magnitude to $-0.0042(0.0009)$ in $1984-1998$ and declines in absolute value steadily thereafter, prior to the Great Recession, to -0.0004 (0.0011) in 1991-2005. The predicted protective effect of unemployment subsequently rises for most analysis windows, including those containing the Great Recession, reaching $-0.0025(0.0015)$ for the 1999 2013 analysis window (see Figure 2A). Figure 2B shows that similar results are obtained using countylevel data but with, if anything, somewhat larger beneficial effects of unemployment estimated during periods of severe national recessions. ${ }^{24}$

Figure 3 shows corresponding results for deaths from disease and external causes separately. ${ }^{25}$ The figure confirms evidence by Ruhm (2015) that the macroeconomic effects are larger and more variable for external than disease sources of mortality. (Note the different scale of the y-axis in Figures 3A and 3B). However, there is no indication that the severe national recessions have negative effects on mortality. For disease mortality there is little discernable evidence of any change over time. ${ }^{26}$ By

\footnotetext{
${ }^{24}$ Ruhm (2015) showed that mortality has become much more procyclical over time, using data for 1976-2010. Figure 2 demonstrates that these conclusions are somewhat modified by extending the analysis through 2013, since the magnitude of the unemployment coefficient increases for the most recent data windows. For instance, it was -0.0010 in 1993-2007 and 0.0025 in 1999-2013 with state data, and changed when using large county data - from -0.0008 to -0.0035 .

${ }^{25}$ External causes include non-disease deaths due to causes like accidents, intentional self-harm, legal intervention or wars.

${ }^{26}$ The unemployment rate coefficient varies over 15 -year analysis windows within a narrow range $(-0.0012$ to -0.0039$)$ and most of the coefficients are not statistically distinguishable from each other.
} 
contrast, while the unemployment rate coefficients vary widely for external mortality (from -0.0189 in 1976-1990 to 0.0148 in 1991-2005), severe national recessions, if anything, appear to have a protective effect, as evidenced by the relatively strong negative unemployment coefficients in the early sample years (that contain the 1980-82 recession) and the elimination of the positive coefficients (implying that unemployment and external deaths were positively related) as data from the Great Recession is included towards the end of the sample timespan.

\section{$\underline{7.2}$ Severe National Recessions and Total Mortality}

Table 6 provides more comprehensive evidence of the protective effect of severe national recessions by summarizing estimates of equations (2) and (2’), using data from states and large counties, and the broad recession definition. The negative severe recession coefficient implies that total mortality rates fall farther during such periods than would be anticipated from the reduction in (state) unemployment rates alone: is an additional $0.5 \%$ decrease in total mortality is predicted when using state data and a $0.9 \%$ reduction when using large counties. These results are largely insensitive to weighting.

Inclusion of the severe recession indicator somewhat attenuates the unemployment rate coefficient, as expected since the former absorbs a portion of the effect of the latter. The estimated severe recession effect is equivalent to the mortality reduction predicted by a two to three percentage point increase in joblessness. ${ }^{27}$ Since, state unemployment rates were 2.3 percentage points higher, on average, during severe recessions than in other years, the total mortality reduction expected during such periods is approximately twice that predicted by higher unemployment rates alone.

I tested the sensitivity of these results to a variety of alternative specifications (with weighted and unweighted data) including: 1) using narrow versus broad definitions of recessions; 2) adding a supplementary control for mild recessions; 3) controlling for all recessions, rather than just severe

\footnotetext{
27 The severe recession coefficient is approximately twice the unemployment parameter estimate for the state sample and three times as large in the large county sample.
} 
recessions. The findings were generally robust to these changes, with severe recessions always strongly predicted to reduce mortality rates.

\subsection{State Economic Crises}

The effects of state economic crises are considered in Table 7, which summarizes estimates of equations (3) and (3’) using unweighted and weighted state or large county data. For each panel, column (1) repeats results for the base specification, without the state crisis variable, while columns (2) through (4) add controls for Crisis 1 through Crisis 3. As a reminder, Crisis 2 indicates more severe downturns than Crisis 1 (unemployment rate ratios above the $95^{\text {th }}$ rather than the $90^{\text {th }}$ percentile), while Crisis 3 requires high absolute unemployment rates as well as ratios.

Overall, state economic crises have modest and inconsistent independent effects on total mortality. The strongest predicted impacts are for Crisis 1 - unemployment rate ratios greater than the $90^{\text {th }}$ percentile - which, with weighting, reduce predicted death rate by around $0.4 \%(0.3 \%)$ when using state (large county) data. To provide perspective, such changes are equivalent to those anticipated from a 0.75 to 1.5 percentage point rise in unemployment, compared to an average increase during crisis periods of over four points (see Table 4). Thus, most of the mortality reduction is captured by the more general macroeconomic effect. Moreover, using classifications focusing on more severe state crises - Crisis 2 or Crisis 3 - the estimated effect is attenuated or becomes slightly (and insignificantly) positive. Thus, while national crises appear to have additional protective effects on mortality, state crises, as measured here, do not.

\subsection{Cause-specific Mortality}

Table 8 considers cause-specific mortality. For each cause, the first row shows the coefficient (and state-clustered robust standard error) on the state unemployment rate. Column (2) shows results for models that also control for severe national recessions (with year effects excluded). Columns (3) through (5) add covariates for the three state economic crisis variables: Crisis 1 through Crisis 3. To 
avoid making the table overly cumbersome, I present results only for models using weighted statelevel data; similar results were obtained for analyses of large counties.

National crises are estimated to have a protective effect on mortality from both diseases and external causes, beyond that predicted by the accompanying elevation of unemployment. This is shown by the negative and significant severe recessions coefficients in column (2) of the first table panel: 0.0045 for diseases and -0.0211 for external causes. Both are equivalent to the mortality reductions predicted from around a 2.5 percentage point increase in unemployment which, as with total mortality, implies that the protective effect is roughly twice that predicted due to the higher rate of joblessness alone.

State economic crises have less consistent effects. Crisis 1 is negatively associated with mortality rates, and the predicted effects are strong and significant, particularly for external deaths. However, the more severe local downturns, represented by Crisis 2 and 3, yield either smaller negative or insignificantly positive predicted effects.

The second panel of Table 8 decomposes disease mortality into cardiovascular sources (CVD), cancer and all other diseases, which respectively account for 44\%, 24\% and 32\% of disease fatalities and $41 \%, 23 \%$ and $30 \%$ of all mortality. Severe national recessions have strong protective effects on deaths from cancer or other diseases but, interestingly, the coefficient is positive and marginally significant for CVD deaths. This does not imply that cardiovascular deaths increase in such periods, since the total effect combines the predicted negative overall unemployment rate effect with the positive severe recession estimate, but it does suggest that the pathways may vary across types of diseases. Similarly, the negative severe recession coefficient for cancer offsets a more general positive effect of rising unemployment rates. However, deaths from other diseases are estimated to fall dramatically during severe national recessions. The parameter estimates once again suggest inconsistent effects of state economic crises, with negative and usually fairly large (but not always 
significant) coefficients for Crisis 1 but frequently positive and sometimes significant effects predicted for Crisis 2 and Crisis 3.

The last panel of Table 8 separately examines four components of external deaths: transport accidents, other (non-transport) accidents, suicides (intentional self-harm) and homicides or other legal intervention. These account for 30\%, 36\%, 20\% and 13\% of external deaths (with a small residual category) but just 2.1\%, 2.5\%, 1.4\% and $0.9 \%$ of all mortality; however, they are of considerable importance given the large cyclical fluctuations.

The patterns for from transport and non-transport accidents are generally similar to those discussed above, with fairly strong (but here statistically insignificant) additional protective effects of severe national recessions, but inconsistent estimates for state crises. Homicides follow a different pattern, with little evidence of a separate severe national recession effect but a stronger and more consistent pattern of extra benefits during state economic crises (although the estimates are less precise than would be desirable).

Perhaps most interesting are the results for suicides. Many earlier analyses have found that suicides are countercyclical, and the positive unemployment rate coefficients here are consistent with that. However, this appears to be substantially offset by the strong and statistically significant negative coefficients for severe national recessions and all three state economic crisis covariates. For instance, at the national level, the severe recession coefficient of -.048 reverses approximately a four percentage point rise in state unemployment rates. Since the latter increase less than three points on average during severe national downturns, suicides are predicted to fall slightly during such periods. The negative coefficients on Crisis 1 through Crisis 3 similarly more than offset the positive unemployment coefficients (recall that joblessness rises by an average of four to five percent during state crises), so that suicides are again predicted to decline slightly.

Appendix Table A.3 summarizes state-level models examining differences in cause-specific mortality effects for the 1980-83 versus the 2008-2010 severe national recessions. The findings are not 
completely consistent with a dose-response relationship. Specifically, the point estimates suggest larger protective effects during the Great Recession than for the somewhat less harsh twin recessions of at the beginning of the 1980s for deaths from all diseases, cardiovascular disease, transport accidents and homicides, but not for mortality due to cancer mortality, other diseases, non-transport accidents or suicides. $^{28}$

\section{Discussion}

The empirical analysis above confirms previous findings of a procyclical fluctuation in U.S. mortality that has declined somewhat over time, particularly during the period of reduced macroeconomic volatility lasting from the early 1980s until the start of the Great Recession. What is new is evidence that the severe national recessions occurring at the beginning of the 1980s and the end of the first decade of the $21^{\text {st }}$ century had a protective effect on total mortality that was around twice as large as that predicted by the higher unemployment rates occurring during such periods alone. These impacts vary across sources of death and it is noteworthy that the national recession coefficients were of the opposite sign for cardiovascular deaths and homicides, suggesting that the protective effect of higher unemployment rates was partially offset during such periods for these causes. Also interesting is that for suicides, which unlike other causes of death are generally countercyclical, the reductions associate with national crises were large enough to fully reverse the general effects of higher rates of unemployment.

These estimates with an important caveat. When using the panel data methods that have now become standard for this type of analysis, year dummy variables are typically included to account for time-varying confounding factors. This is not possible when considering national crises, since the impacts would be absorbed by the vector of time effects, raising the possibility of omitted variables

\footnotetext{
${ }^{28}$ I examined the effects of state economic crises in models without time dummy variables. The protective effects of state crises were more pronounced in these specifications, but again without evidence of stronger effects for the more severe crises (i.e. Crisis 2 or 3 versus Crisis 1). I also estimated models with national and state crises, and interactions between them, simultaneously included. When doing so, severe recessions had large and significant predicted protective effects, state crises less consistent (but sometimes protective) impacts, while the interaction coefficient was of inconsistent sign and statistically insignificant.
} 
bias. There are reasons to doubt that importance of this concern. First, the unemployment coefficients obtained from models similar to those used in prior research were generally not sensitive to the inclusion of year dummy variables. Second, most estimates indicate a "dose-response" relationship in the severe recessions, whereby the effects of the Great Recession were somewhat greater than those of the still severe but somewhat less devastating twin downturns occurring during the early 1980s. However, this was not true for all of the cause-specific models. The exceptions provide an additional reason for interpreting the results with caution.

There was not a consistent pattern of findings for the three variables used to proxy state economic crises. When these were defined as unemployment rates ratios (current unemployment rates divided by state average rates) greater than the $90^{\text {th }}$ percentile, a protective effect on mortality was usually obtained, just as with national crises. However, when using more stringent classification criteria, the predicted effects were generally weaker or opposite signed.

Further research is needed to better understand the differences between the effects of national versus more localized economic traumas observed here, and to identify the sources of heterogeneity across sources of death. More fundamentally, the definition of economic crisis is not clear-cut and it would be useful to ascertain whether the results are sensitive to the use of reasonable alternative definitions. Also, these determinations should be tempered by the understanding that economic crises may contain idiosyncratic elements that affect mortality. For instance, the breakup of the Soviet Union had enormous negative effects on Russian life expectancy, in part, because declines in alcohol prices led to increases alcohol-related problems. Conversely, the Icelandic banking collapse in 2008 resulted in a currency devaluations that raised alcohol and cigarette prices, leading to reductions in drinking and smoking.

These caveats notwithstanding, this analysis, when combined with previous related research, provides reasonably strong evidence that the protective effect of economic downturns on physical health is generally not restricted to "typical" business cycle fluctuations, but also extends to crisis 
periods, at least when the latter do not lead to a the collapse of the health infrastructure or large changes in relative prices.

\section{References}

Anderson, Robert N., Arialdi M. Miniño, Donna L. Hoyert and Harry M. Rosenberg (2001) "Comparability of Cause of Death Between ICD-9 and ICD-10: Preliminary Estimates." National Vital Statistics Reports 49(2), 1-32.

Ariizumi, Hideki and Tammy Schirle (2012) Are Recesions Really Good for Your Health? Evidence from Canada Social Science and Medicine 74, 1224-1231.

Arkes, Jeremy (2007) “Does the Economy Affect Teenage Substance Use?” Health Economics 16(1), 19-36.

Ásgeirsdóttir, Tinna L., Hope Cormon, Kelly Noonan, Pórhildur Ólafsdóttir and Nancy Reichman. (2014) "Was the Economic Crisis of 2008 Good for Icelanders? Impact on Health Behaviors", Economics and Human Biology, 14, 1-19.

Ásgeirsdóttir, Tinna L., Hope Cormon, Kelly Noonan, and Nancy Reichman. 2015. "Lifecycle Effects of a Recession on Health Behaviors: Boom, Bust, and Recovery in Iceland”, NBER Working Paper No. 20950, February.

Brainerd, Elizabeth and David Cutler. 2005 “Autopsy on An Empire: Understanding Mortality in Russia and the Former Soviet Union” Journal of Economic Perspectives, 19(1), 107-130.

Brenner, M. Harvey (1971) “Economic Changes and Heart Disease Mortality.” American Journal of Public Health 61(3), 606-611.

Brenner, M. Harvey (1979) "Mortality and the National Economy.” The Lancet 314(8142), 568-73.

Brenner, M. Harvey (1987) "Economic Change, Alcohol Consumption and Heart Disease Mortality in Nine Industrialized Countries" Social Science and Medicine 25(2), 119-32.

Buchmueller, Tom, Michel Grignon and Flrence Jusot (2007) "Unemployment and Mortality in France, 1982-2002” Center for Health Economics and Policy Analysis Working Paper 07-04, McMaster University.

Charles, Kerwin Kofi and Philip DeCicca (2008) "Local Labor Market Fluctuations and Health: Is there a Connection and For Whom?” Journal of Health Economics 27(6), 1532-1550.

Colman Gregory J and Dhaval M. Dave (2013) "Exercise, Physical Activity, and Exertion Over the Business Cycle.” Social Science and Medicine 93 (September), 11-20..

Dávlos María E, Hai Fang and Michael T. French (2012) "Easing the Pain of an Economic Downturn: Macroeconomic Conditions and Excessive Alcohol Consumption” Health Economics 21(11) 1318-1335.

Economou, Athina, Agelike Nikolau, and Ioannis Theodossiou (2008) "Are Recessions Harmful to Health After All? Evidence from the European Union.” Journal of Economic Studies 35(5), 368384.

Edwards, Ryan (2011) “American Time Use Over the Business Cycle.” Mimeo, City University of New York. 
Eyer, Joseph (1977) “Prosperity as a Cause of Death.” International Journal of Health Services 7(1), 125-150.

Fishback, Price V., Michael R. Haines and Shawn Kantor (2007) "Births, Deaths and New Deal Relief During the Great Depression.” Review of Economics and Statistics 89(1), 1-14.

Forbes John F. and Alan McGregor (1984) “Unemployment and Mortality in Post-War Scotland” Journal of Health Economics 3(3), 239-57

Gerdtham, Ulf-G and Magnus Johannesson (2005) "Business Cycles and Mortality: Results from Swedish Microdata” Social Science and Medicine 60(1), 205-218.

Gerdtham, Ulf-G and Christopher J. Ruhm (2006) "Deaths Rise in Good Economic Times: Evidence from the OECD.” Economics and Human Biology 43(3), 298-316.

Gonzalez, Fidel and Troy Quast (2011) “Macroeconomic Changes and Mortality in Mexico.” Empirical Economics 40(2), 305-319.

Gravelle, H.S.E., G. Hutchinson and J. Stern (1981) "Mortality and Unemployment: A Critique of Brenner’s Time-Series Analysis.” The Lancet 318(8248), 675-679.

Gruber, Jonathan and Michael Frakes (2006) “Does Falling Smoking Lead to Rising Obesity?” Journal of Health Economics_25(2), 183-197.

Joyce, Theodore J. and H. Naci Mocan (1993) “Unemployment and Infant Health: Time-Series Evidence from the State of Tennessee” Journal of Human Resources 28(1), 185-203.

Kasl, Stanislav V. (1979) "Mortality and the Business Cycle: Some Questions about Research Strategies When Utilizing Macro-Social and Ecological Data.” American Journal of Public Health 69(8), 784-788.

Klebba A. Joan and Joyce H. Scott (1980) “Estimates of Selected Comparability Ratios Based on Dual Coding of 1976 Death Certificates by the Eighth and Ninth Revisions of the International Classifications of Diseases.” Monthly Vital Statistics Report 28(11), 1-19.

Laporte, Audrey (2004) “Do Economic Cycles Have a Permanent Effect on Population Health? Revisiting the Brenner Hypothesis” Health Economics 13(8), 767-79.

Lin, Shin-Jong (2009) "Economic Fluctuations and Health Outcome: A Panel Analysis of AsiaPacific Countries.” Applied Economics 41(4), 519-530.

Lindo, Jason M. (2015) “Aggregation and the Relationship Between Unemployment and Health,” Journal of Health Economics, 40, 83-96.

McInerney Melissa and Jennifer M. Mellor (2012) "Recessions and Seniors' Health, Health Behaviors, and Healthcare Use: Analysis of the Medicare Beneficiary Survey.” Journal of Health Economics 31(5), 744-751.

Modrek, Sepideh, David Stuckler, Marin McKee, Mark R. Cullen and Sanjay Basu (2013) “A Review of Health Consequences of Recessions Internationally and a Synthesis of the US Response During the Great Recession.” Public Health Reviews 35(1), 1-33.

Neumayer, Eric (2004) “Recessions Lower (Some) Mortality Rates.” Social Science \& Medicine 58(6), 1037-1047.

Ogburn, William F. and Dorothy S. Thomas (1922) "The Influence of the Business Cycle on Certain Social Conditions.” Journal of the American Statistical Association 18(139), 324-340. 
Ruhm, Christopher J. (2000) “Are Recessions Good For Your Health?” Quarterly Journal of Economics 115(2), 617-650.

Ruhm, Christopher J. (2003) “Good Times Make You Sick.” Journal of Health Economics 22(4), 637-658.

Ruhm, Christopher J. (2005) “Healthy Living in Hard Times.” Journal of Health Economics 24(2), 341-63.

Ruhm, Christopher J. (2012) Understanding the Relationship Between Macroeconomic Conditions and Health. In Andrew M. Jones (ed.) Elgar Companion to Health Economics, $2^{\text {nd }}$ Edition. Cheltenham, UK: Edward Elgar, 5-14.

Ruhm, Christopher J. (2015) “Recessions, Healthy No More?” Journal of Health Economics 42, 1728.

Ruhm, Christopher J. and William E. Black (2002) “Does Drinking Really Decrease in Bad Times?” Journal of Health Economics 21(4), 659-678.

Stevens, Ann Huff, Douglas L. Miller, Marianne Page and Mateusz Filipski (2011) “The Best of Times, The Worst of Times: Understanding Procyclical Mortality.” NBER Working Paper No. 17657.

Stuckler, David, Sanjay Basu, Marc Suhrcke, Adam Coutts, and Martin McKee (2009) “The Public Health Effect of Economic Crisis and Alternative Policy Responses in Europe: An Empirical Analysis.” The Lancet 374(9686), 315-323.

Stuckler, David, Christopher Meissner, Price Fishback, Sanjay Basu and Martin McKee (2012) "Banking Crisis and Mortality During the Great Depression: Evidence from US Urban Populations, 1929-1937.” Journal of Epidemiology and Community Health 66(5), 410-19.

Sullivan, Daniel and Till von Wachter (2009) “Job Displacement and Mortality: An Analysis Using Administrative Data.” Quarterly Journal of Economics 124(3), 1265-1306.

Svensson Mikael (2007) "Do Not Go Breaking Your Heart: Do Economic Upturns Really Increase Heart Attack Mortality?” Social Science and Medicine 65(4), 833-841.

Tapia Granados, José A. (2005) “Recessions and Mortality in Spain, 1980-1997.” European Journal of Population 21(4), 393-422.

Tapia Granados, José A. and Edward L. Ionides (2008) “The Reversal of the Relationship Between Economic Growth and Health Progress: Sweden in the $19^{\text {th }}$ and $20^{\text {th }}$ Centuries” Journal of Health Economics 27(3), 544-563.

Tapia Granados, José A. and Ana V. Diez Roux (2009) “Life and Death During the Great Depression.” Proceedings of the National Academy of Sciences 106(41), 17290-17295.

Tekin, Erdal, Chandler McClellan and Karen Jean Minyard (2013) "Health and Health Behaviors During the Worst of Times: Evidence from the Great Recession” NBER Working Paper No. 19234.

Thomas, Dorothy Swaine (1927) Social Aspects of the Business Cycle. New York: Alfred A. Knopf. Toffolutti, Veronica and Marc Suhcke (2014) “Assessing the Short Term Health Impact of the Great Recession in the European Union: A Cross-County Panel Analysis.” Preventive Medicine 64, 5462. 
van Gool, Kees and Mark Pearson (2014) "Health, Austerity and Economic Crisis: Assessing the Short-term Impact in OECD Countries” OECD Health Working Papers No. 76, OECD Publishing.

Wagstaff, Adam (1985) “Time Series Analysis of the Relationship Between Unemployment and Mortality: A Survey of Econometric Critiques and Replications of Brenner's Studies” Social Science and Medicine 21(9), 985-96.

Xu Xin (2013) “The Business Cycle and Health Behaviors.” Social Science and Medicine 77, January 2013, 126-136. 
Table 1: Recession Dates and Characteristics

\begin{tabular}{|c|c|c|c|c|c|}
\hline \multirow{2}{*}{ Recession Dates } & \multirow{2}{*}{$\begin{array}{l}\text { Duration } \\
\text { (months) }\end{array}$} & \multirow{2}{*}{$\begin{array}{l}\text { \% GDP } \\
\text { Decline } \\
\text { (peak to } \\
\text { trough) }\end{array}$} & \multicolumn{2}{|c|}{$\begin{array}{c}\text { Annual Unemployment } \\
\text { Rate }\end{array}$} & \multirow{2}{*}{ Classification } \\
\hline & & & $\begin{array}{l}\text { Peak \% } \\
\text { (year) }\end{array}$ & $\begin{array}{c}\text { \% Point } \Delta \\
\text { (from } \\
\text { trough) }\end{array}$ & \\
\hline 1/1980 - 7/1980 & 6 & -2.2 & 9.7 & \multirow{2}{*}{$3.9 \%$} & \multirow{2}{*}{ Severe } \\
\hline 7/1981 -11/1982 & 16 & -2.7 & (1982) & & \\
\hline 7/1990 - 3/1991 & 8 & -1.4 & $\begin{array}{c}7.5 \\
(1992)\end{array}$ & $2.2 \%$ & Mild \\
\hline $3 / 2001-11 / 2001$ & 8 & -0.3 & $\begin{array}{c}6.0 \\
(2003)\end{array}$ & $2.0 \%$ & Mild \\
\hline $12 / 2007-6 / 2009$ & 18 & -4.3 & $\begin{array}{c}9.6 \\
(2010)\end{array}$ & $5.0 \%$ & Severe \\
\hline
\end{tabular}

Note: 1980 and 1981/82 are treated as a single recession. Peak unemployment rate refers to the year with the highest annual unemployment rate either during or immediately following the recession. Change from trough refers to the increase in unemployment from the lowest annual unemployment rate prior to the start of the recession. The last column shows the classification of recession severity used below. Sources: http://www.nber.org/cycles.html; https://en.wikipedia.org/wiki/List_of_recessions_in_the_United_States; http://www.gpo.gov/fdsys/pkg/ERP-2015/pdf/ERP-2015-table12.pdf. 
Table 2: Average State Unemployment Rates in Recession and Non-Recession Years

Category

Narrow Recession Definition Broad Recession Definition

\begin{tabular}{lcccc} 
& No & Yes & No & Yes \\
\hline Any Recession & $6.31 \%$ & $7.27 \%$ & $6.01 \%$ & $7.41 \%$ \\
Mild Recession & $6.31 \%$ & $5.78 \%$ & $6.01 \%$ & $6.30 \%$ \\
Severe Recession & $6.28 \%$ & $7.87 \%$ & $6.07 \%$ & $8.36 \%$ \\
\hline
\end{tabular}

Note: Table shows the average state unemployment rate in recession and non-recession years, with the data weighted by state-specific average populations. For mild recessions, severe recessions are excluded from the calculations of unemployment rates in non-recession years. Data are for 1,938 observations from the 50 states and District of Columbia, from 1976-2013. Narrow definition of Recessions refers to the years: 1980-82, 1991, 2001 and 2008-09. The broad definition includes these years plus immediate post-recession years with unemployment rates higher than the peak recession year: 1980-83, 1991-93, 2001-05, 2008-10. Narrow definition of Mild Recession refers to 1991 and 2001 and the broad definition to 1991-93 and 2001-2003. Narrow definition of Severe Recession refers to years 1980-82 and 2008-09, and the broad definition to 1980-83 and 2008-10. 
Table 3: Unemployment Rates, Ratios and Changes by State Economic “Crisis” Status

\begin{tabular}{|c|c|c|c|c|c|c|}
\hline \multirow{2}{*}{ Variable } & \multirow{2}{*}{ Description } & \multirow{2}{*}{ Status } & \multicolumn{2}{|c|}{$\underline{\text { Share of Observations }}$} & \multicolumn{2}{|c|}{$\underline{\text { Sample Means }}$} \\
\hline & & & Unweighted & Weighted & UN Rate & UN Ratio \\
\hline \multirow{2}{*}{ Crisis 1} & \multirow{2}{*}{ UN Ratio: $>90^{\text {th }}$ percentile $(>1.377)$} & No & $89.5 \%$ & $90.0 \%$ & $6.07 \%$ & 0.937 \\
\hline & & Yes & $10.5 \%$ & $10.0 \%$ & $10.23 \%$ & 1.567 \\
\hline \multirow{2}{*}{ Crisis 2} & \multirow{2}{*}{ UN Ratio:>95th percentile $(>1.541)$} & No & $95.0 \%$ & $94.9 \%$ & $6.25 \%$ & 0.964 \\
\hline & & Yes & $5.0 \%$ & $5.1 \%$ & $10.94 \%$ & 1.669 \\
\hline \multirow{2}{*}{ Crisis 3} & UN Ratio: $>90^{\text {th }}$ percentile $(>1.377) \&$ & No & $94.5 \%$ & $93.1 \%$ & $6.25 \%$ & 0.956 \\
\hline & UN Rate: $>90^{\text {th }}$ percentile (>9.30\%) & Yes & $5.5 \%$ & $6.9 \%$ & $11.48 \%$ & 1.601 \\
\hline
\end{tabular}

Note: Unemployment rate ratio (UN Ratio) is the current year state unemployment rate (UN Rate) divided by the average state unemployment rate over the full (1976-2013) time period. UN rate is the state unemployment rate. For sample means, observations are weighted by state average populations. For Crisis 3, the unemployment rate percentile refers to all state-year unemployment rates. 
Table 4: National Total Mortality Regressions

\begin{tabular}{|c|c|c|c|c|c|c|}
\hline Regressors & (1) & (2) & (3) & (4) & (5) & (6) \\
\hline Unemployment Rate & $\begin{array}{c}-0.0050^{* * *} \\
(0.0014)\end{array}$ & $\begin{array}{c}-0.0030 * * \\
(0.0014)\end{array}$ & $\begin{array}{c}-0.0040 * * * \\
(0.0013)\end{array}$ & $\begin{array}{c}-0.0032^{* *} \\
(0.0014)\end{array}$ & $\begin{array}{l}-0.0029 * \\
(0.0015)\end{array}$ & $\begin{array}{l}-2.4176^{*} \\
(1.1977)\end{array}$ \\
\hline Severe Recession & & $\begin{array}{c}-0.0141^{* * *} \\
(0.0047)\end{array}$ & $\begin{array}{c}-0.0134 * * * \\
(0.0043)\end{array}$ & $\begin{array}{c}-0.0115^{* *} \\
(0.0047)\end{array}$ & & $\begin{array}{c}-11.8153^{* * *} \\
(3.9422)\end{array}$ \\
\hline Severe Recession: 1980-83 & & & & & $\begin{array}{l}-0.0077 \\
(0.0073)\end{array}$ & \\
\hline Great Recession: 2008-10 & & & & & $\begin{array}{c}-0.0224^{* * *} \\
(0.0056)\end{array}$ & \\
\hline Time Trend & $\begin{array}{c}-0.0871^{* * * *} \\
(0.0092)\end{array}$ & $\begin{array}{c}-0.0867 * * * \\
(0.0090)\end{array}$ & $\begin{array}{c}-0.0878 * * * \\
(0.0092)\end{array}$ & $\begin{array}{c}-0.0879 * * * \\
(0.0087)\end{array}$ & $\begin{array}{c}-0.0810^{* * *} \\
(0.0118)\end{array}$ & $\begin{array}{c}-72.7576^{* * * *} \\
(7.5311)\end{array}$ \\
\hline Additional Details/Notes & N/A & N/A & $\begin{array}{c}\text { Narrow Severe } \\
\text { Recession } \\
\text { Definition }\end{array}$ & $\begin{array}{c}\text { Mild } \\
\text { Recessions } \\
\text { Controlled For }\end{array}$ & $\mathrm{N} / \mathrm{A}$ & $\begin{array}{l}\text { Mortality in } \\
\text { Levels }\end{array}$ \\
\hline
\end{tabular}

Note: Table shows regression coefficients where the dependent variable is the natural log of the national total mortality rate per 100,000 , except in model (6) where it is the mortality rate per 100,000 in levels. Sample period is 1976 -2013 ( $\mathrm{n}=38$ ). Severe Recession is a dummy variable indicating the years 1980-1983 and 2008-2010, except in model (3), where the years are 1980-82 and 2008-2009. Mild recession refers to the years 1991-1993 and 2001-2003. All models also control for a linear national time trend. *** $\mathrm{p}<0.01, * * \mathrm{p}<0.05, * \mathrm{p}<0.1$. 
Table 5: State and County Total Mortality Regressions

\begin{tabular}{lcccc}
\hline & $\mathbf{( 1 )}$ & $\mathbf{( 2 )}$ & $\mathbf{( 3 )}$ & $\mathbf{( 4 )}$ \\
\hline States & $-0.0035^{* * *}$ & $-0.0033^{* * *}$ & $-0.0030^{* * *}$ & $-0.0032^{* * *}$ \\
& $(0.0004)$ & $(0.0007)$ & $(0.0003)$ & $(0.0008)$ \\
\hline Counties & $-0.0045^{* * *}$ & $-0.0032^{* * *}$ & $-0.0042^{* * *}$ & $-0.0044^{* * *}$ \\
& $(0.0004)$ & $(0.0008)$ & $(0.0003)$ & $(0.0009)$ \\
\hline “Large” Counties & $-0.0042^{* * *}$ & $-0.0038^{* * *}$ & $-0.0041^{* * *}$ & $-0.0044 * * *$ \\
& $(0.0003)$ & $(0.0008)$ & $(0.0003)$ & $(0.0009)$ \\
\hline Sample Weights & No & No & Yes & Yes \\
Year Effects & No & Yes & No & Yes \\
\hline
\end{tabular}

Note: Dependent variable is the natural log of the total mortality rate. Table displays coefficient on the state unemployment rate. Data are for the 50 states plus the District of Columbia $(n=1,938)$ for 1976-2013 in the first panel, for all 3,142 counties the second $(n=118,326)$, and for the 1,515 "large" counties with a population size averaging more than 25,000 persons over the entire period in the third $(n=57,097)$. The regressions also include vectors of location dummy variables, location-specific linear time trends, and controls for the share of the county population who are: female, black, other nonwhite, and aged $<1,1-19,45-54,55-64,65-74,75-84$ and $\geq 85$ years old. Year dummy variables are included in columns (2) and (4), and the data are weighted by location-specific average populations in columns (3) and (4). Robust standard errors, clustered at the state level, are in parentheses. ${ }^{* * *} \mathrm{p}<0.01,{ }^{* *} \mathrm{p}<0.05,{ }^{*} \mathrm{p}<0.1$. 
Table 6: Total Mortality Regressions with Controls for Severe National Recessions

Unweighted Weighted

Regressor

(2)

(3)

(4)

(5)

(6)

\begin{tabular}{|c|c|c|c|c|c|c|}
\hline \multicolumn{7}{|c|}{ States } \\
\hline Unemployment Rate & $\begin{array}{c}-0.0035^{* * *} \\
(0.0004)\end{array}$ & $\begin{array}{c}-0.0031 * * * \\
(0.0005)\end{array}$ & $\begin{array}{c}-0.0031^{* * *} \\
(0.0005)\end{array}$ & $\begin{array}{c}-0.0030 * * * \\
(0.0003)\end{array}$ & $\begin{array}{c}-0.0025 * * * \\
(0.0004)\end{array}$ & $\begin{array}{c}-0.0025^{* * *} \\
(0.0004)\end{array}$ \\
\hline Severe Recession & & $\begin{array}{c}-0.0048 * * * \\
(0.0018)\end{array}$ & & & $\begin{array}{c}-0.0053 * * * \\
(0.0015)\end{array}$ & \\
\hline Severe Recession: 1980-83 & & & $\begin{array}{l}-0.0039 \\
(0.0025)\end{array}$ & & & $\begin{array}{c}-0.0041^{*} \\
(0.0023)\end{array}$ \\
\hline Great Recession: 2008-10 & & & $\begin{array}{c}-0.0058^{* * *} \\
(0.0020)\end{array}$ & & & $\begin{array}{c}-0.0068 * * * \\
(0.0014)\end{array}$ \\
\hline \multicolumn{7}{|c|}{ “Large Counties } \\
\hline Unemployment Rate & $\begin{array}{c}-0.0042 * * * \\
(0.0003)\end{array}$ & $\begin{array}{c}-0.0032 * * * \\
(0.0004)\end{array}$ & $\begin{array}{c}-0.0032 * * * \\
(0.0004)\end{array}$ & $\begin{array}{c}-0.0041^{* * *} \\
(0.0003)\end{array}$ & $\begin{array}{c}-0.0031 * * * \\
(0.0004)\end{array}$ & $\begin{array}{c}-0.0033^{* * *} \\
(0.0004)\end{array}$ \\
\hline Severe Recession & & $\begin{array}{c}-0.0100 * * * \\
(0.0017)\end{array}$ & & & $\begin{array}{c}-0.0093 * * * \\
(0.0020)\end{array}$ & \\
\hline Severe Recession: $1980-83$ & & & $\begin{array}{c}-0.0095 * * * \\
(0.0028)\end{array}$ & & & $\begin{array}{c}-0.0072 * * \\
(0.0030)\end{array}$ \\
\hline Great Recession: 2008-10 & & & $\begin{array}{c}-0.0107 * * * \\
(0.0010)\end{array}$ & & & $\begin{array}{c}-0.0120 * * * \\
(0.0013)\end{array}$ \\
\hline
\end{tabular}

Note: Dependent variable is the natural log of the total mortality rate. First row of each panel displays coefficient on the state unemployment rate. Second row shows coefficient on an indicator of severe national recessions, corresponding to the years 1980-83 and 2008-10. Third and fourth rows break these recessions out separately. State data are for 1,938 observations from the 50 states and District of Columbia for 1976-2013. "Large” county data are for the 57,097 observations in 1,515 counties with a population size 
averaging more than 25,000 persons over the entire period. Severe Recession is a dummy variable indicating the years 1980 -1983 and 2008-2010. The regressions also include vectors of location dummy variables, location-specific linear time trends and controls for the share of the county population who are: female, black, other nonwhite, and aged $<1,1-19,45-54,55-64,65-74$, 75-84 and $\geq 85$ years old. The data are weighted by location-specific average populations in columns (4) through (6). Robust standard errors, clustered at the state level, are in parentheses. ${ }^{* * *} \mathrm{p}<0.01,{ }^{* *} \mathrm{p}<0.05,{ }^{*} \mathrm{p}<0.1$. 
Table 7: Total Mortality Regressions with State Economic "Crisis" Covariates

\begin{tabular}{lcccc} 
Sample/Regressors & $\mathbf{( 1 )}$ & $\mathbf{( 2 )}$ & $\mathbf{( 3 )}$ & $\mathbf{( 4 )}$ \\
\hline States: Unweighted & & & & \\
Unemployment Rate & $-0.0033^{* * *}$ & $-0.0027^{* * *}$ & $-0.0032^{* * *}$ & $-0.0035^{* * *}$ \\
& $(0.0007)$ & $(0.0008)$ & $(0.0008)$ & $(0.0008)$ \\
Economic Crisis & & $-0.0046^{* *}$ & -0.0006 & 0.0026 \\
& & $(0.0021)$ & $(0.0029)$ & $(0.0023)$ \\
\hline States: Weighted & & & & \\
Unemployment Rate & $-0.0032^{* * *}$ & $-0.0027^{* * *}$ & $-0.0034^{* * *}$ & $-0.0035^{* * *}$ \\
& $(0.0008)$ & $(0.0009)$ & $(0.0009)$ & $(0.0009)$ \\
Economic Crisis & & $-0.0041^{* *}$ & 0.0019 & 0.0021 \\
& & $(0.0017)$ & $(0.0021)$ & $(0.0020)$ \\
\hline
\end{tabular}

\section{"Large" Counties: Unweighted}

\begin{tabular}{|c|c|c|c|c|}
\hline Unemployment Rate & $\begin{array}{c}-0.0038 * * * \\
(0.0008)\end{array}$ & $\begin{array}{c}-0.0032^{* * *} \\
(0.0009)\end{array}$ & $\begin{array}{c}-0.0037^{* * *} \\
(0.0009)\end{array}$ & $\begin{array}{c}-0.0041^{* * *} \\
(0.0008)\end{array}$ \\
\hline Economic Crisis & & $\begin{array}{c}-0.0048^{*} \\
(0.0024)\end{array}$ & $\begin{array}{l}-0.0017 \\
(0.0034)\end{array}$ & $\begin{array}{c}0.0025 \\
(0.0024)\end{array}$ \\
\hline \multicolumn{5}{|c|}{ "Large” Counties: Weighted } \\
\hline Unemployment Rate & $\begin{array}{c}-0.0044 * * * \\
(0.0009)\end{array}$ & $\begin{array}{c}-0.0040 * * * \\
(0.0010)\end{array}$ & $\begin{array}{c}-0.0045^{* * *} \\
(0.0010)\end{array}$ & $\begin{array}{c}-0.0048 * * * \\
(0.0010)\end{array}$ \\
\hline Economic Crisis & & $\begin{array}{c}-0.0028 \\
(0.0021) \\
\end{array}$ & $\begin{array}{c}0.0016 \\
(0.0024) \\
\end{array}$ & $\begin{array}{c}0.0033 \\
(0.0021) \\
\end{array}$ \\
\hline
\end{tabular}

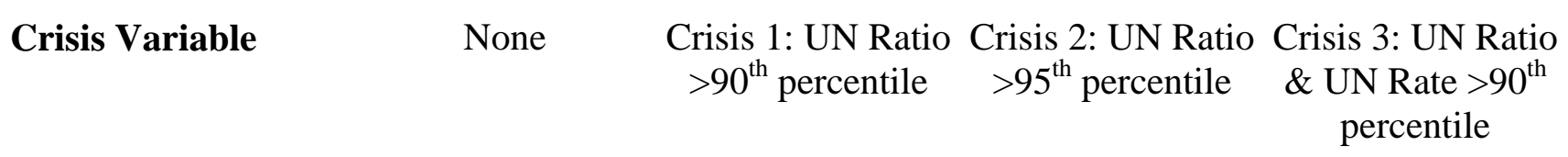

Note: Dependent variable is the natural log of the total mortality rate. First row of each panel displays the coefficient on the state unemployment rate. The second row shows the coefficient on the economic "crisis" variable displayed on the last panel of the table. Crisis 1 is a dummy variable indicating observations $>90^{\text {th }}$ percentile $(>1.377)$ ) of the unemployment rate ratio (UN Ratio). Crisis 2 indicates unemployment rate ratios $>95^{\text {th }}$ percentile $(>1.541)$. Crisis 3 indicates that both the UN Ratio and UN Rate are $>90^{\text {th }}$ percentile ( $>1.377$ and $>9.3 \%$ ). State data are for 1,938 observations from the 50 states and District of Columbia for 1976-2013 (first two panels). "Large" county data are for the 57,097 observations in 1,515 counties with a population size averaging more than 25,000 persons over the entire period (third and fourth panels). Regressions also include location and year dummy variables, location-specific linear time trends and controls for the share of the county population who are: female, black, other nonwhite, and aged $<1,1-19$, $45-54,55-64,65-74,75-84$ and $\geq 85$ years old. Data are weighted by location-specific average populations in the second and fourth panels. Robust standard errors, clustered at the state level are in parentheses. ${ }^{* * *} \mathrm{p}<0.01,{ }^{* *} \mathrm{p}<0.05,{ }^{*} \mathrm{p}<0.1$. 
Table 8: Cause-Specific Mortality Regressions with National \& State Economic "Crisis" Covariates

\begin{tabular}{|c|c|c|c|c|c|}
\hline Source/Regressors & (1) & (2) & (3) & $(4)$ & (5) \\
\hline \multicolumn{6}{|l|}{ Diseases } \\
\hline Unemployment Rate & $\begin{array}{c}-0.0029 * * * \\
(0.0008)\end{array}$ & $\begin{array}{c}-0.0019 * * * \\
(0.0004)\end{array}$ & $\begin{array}{c}-0.0024^{* *} \\
(0.0009)\end{array}$ & $\begin{array}{c}-0.0030 * * * \\
(0.0009)\end{array}$ & $\begin{array}{c}-0.0031 * * * \\
(0.0009)\end{array}$ \\
\hline Economic Crisis & & $\begin{array}{c}-0.0045^{* *} \\
(0.0017)\end{array}$ & $\begin{array}{c}-0.0033^{* *} \\
(0.0016)\end{array}$ & $\begin{array}{c}0.0024 \\
(0.0020)\end{array}$ & $\begin{array}{c}0.0023 \\
(0.0020)\end{array}$ \\
\hline \multicolumn{6}{|l|}{ External Causes } \\
\hline Unemployment Rate & $\begin{array}{c}-0.0080 * * * \\
(0.0020)\end{array}$ & $\begin{array}{c}-0.0085^{* * *} \\
(0.0014)\end{array}$ & $\begin{array}{c}-0.0056^{* * *} \\
(0.0021)\end{array}$ & $\begin{array}{c}-0.0075^{* * *} \\
(0.0022)\end{array}$ & $\begin{array}{c}-0.0081 * * * \\
(0.0022)\end{array}$ \\
\hline Economic Crisis & & $\begin{array}{c}-0.0211^{* * *} \\
(0.0070) \\
\end{array}$ & $\begin{array}{c}-0.0180^{* *} \\
(0.0071) \\
\end{array}$ & $\begin{array}{c}-0.0062 \\
(0.0075) \\
\end{array}$ & $\begin{array}{c}0.0008 \\
(0.0080) \\
\end{array}$ \\
\hline \multicolumn{6}{|l|}{ Cardiovascular Disease } \\
\hline Unemployment Rate & $\begin{array}{c}-0.0044 * * * \\
(0.0010)\end{array}$ & $\begin{array}{c}-0.0034^{* * *} \\
(0.0007)\end{array}$ & $\begin{array}{c}-0.0040 * * * \\
(0.0013)\end{array}$ & $\begin{array}{c}-0.0045^{* * *} \\
(0.0011)\end{array}$ & $\begin{array}{c}-0.0044^{* * * *} \\
(0.0011)\end{array}$ \\
\hline Economic Crisis & & $\begin{array}{l}0.0047^{*} \\
(0.0025)\end{array}$ & $\begin{array}{c}-0.0032 \\
(0.0032)\end{array}$ & $\begin{array}{c}0.0003 \\
(0.0028)\end{array}$ & $\begin{array}{l}-0.0007 \\
(0.0033)\end{array}$ \\
\hline \multicolumn{6}{|l|}{ Cancer } \\
\hline Unemployment Rate & $\begin{array}{c}0.0017 * * * \\
(0.0005)\end{array}$ & $\begin{array}{c}0.0015 * * * \\
(0.0004)\end{array}$ & $\begin{array}{c}0.0022^{* * *} \\
(0.0006)\end{array}$ & $\begin{array}{c}0.0018 * * * \\
(0.0006)\end{array}$ & $\begin{array}{c}0.0016^{* *} \\
(0.0006)\end{array}$ \\
\hline Economic Crisis & & $\begin{array}{c}-0.0050 * * * \\
(0.0018)\end{array}$ & $\begin{array}{c}-0.0035^{* *} \\
(0.0017)\end{array}$ & $\begin{array}{l}-0.0015 \\
(0.0027)\end{array}$ & $\begin{array}{c}0.0011 \\
(0.0023)\end{array}$ \\
\hline \multicolumn{6}{|l|}{ Other Disease } \\
\hline Unemployment Rate & $\begin{array}{c}-0.0042^{* *} \\
(0.0017)\end{array}$ & $\begin{array}{c}-0.0029 * * * \\
(0.0008)\end{array}$ & $\begin{array}{c}-0.0041^{*} \\
(0.0021)\end{array}$ & $\begin{array}{c}-0.0049 * * \\
(0.0019)\end{array}$ & $\begin{array}{c}-0.0055^{* *} \\
(0.0022)\end{array}$ \\
\hline Economic Crisis & & $\begin{array}{c}-0.0207 * * * \\
(0.0041) \\
\end{array}$ & $\begin{array}{c}-0.0011 \\
(0.0044)\end{array}$ & $\begin{array}{c}0.0079 * \\
(0.0042) \\
\end{array}$ & $\begin{array}{l}0.0106^{*} \\
(0.0059) \\
\end{array}$ \\
\hline \multicolumn{6}{|l|}{ Transport Accidents } \\
\hline Unemployment Rate & $\begin{array}{c}-0.0269 * * * \\
(0.0032)\end{array}$ & $\begin{array}{c}-0.0311^{* * *} \\
(0.0016)\end{array}$ & $\begin{array}{c}-0.0258 * * * \\
(0.0038)\end{array}$ & $\begin{array}{c}-0.0262 * * * \\
(0.0036)\end{array}$ & $\begin{array}{c}-0.0278 * * * \\
(0.0038)\end{array}$ \\
\hline Economic Crisis & & $\begin{array}{l}-0.0096 \\
(0.0117)\end{array}$ & $\begin{array}{c}-0.0081 \\
(0.0099)\end{array}$ & $\begin{array}{l}-0.0086 \\
(0.0092)\end{array}$ & $\begin{array}{c}0.0073 \\
(0.0101)\end{array}$ \\
\hline \multicolumn{6}{|l|}{ Other Accidents } \\
\hline Unemployment Rate & $\begin{array}{c}-0.0031 \\
(0.0044)\end{array}$ & $\begin{array}{c}-0.0064 * * \\
(0.0027)\end{array}$ & $\begin{array}{c}-0.0011 \\
(0.0048)\end{array}$ & $\begin{array}{c}-0.0032 \\
(0.0046)\end{array}$ & $\begin{array}{c}-0.0033 \\
(0.0046)\end{array}$ \\
\hline Economic Crisis & & $\begin{array}{l}-0.0112 \\
(0.0073)\end{array}$ & $\begin{array}{l}-0.0154 \\
(0.0116)\end{array}$ & $\begin{array}{c}0.0013 \\
(0.0094)\end{array}$ & $\begin{array}{c}0.0018 \\
(0.0092)\end{array}$ \\
\hline \multicolumn{6}{|l|}{ Suicides } \\
\hline Unemployment Rate & $\begin{array}{c}0.0114^{* * *} \\
(0.0038)\end{array}$ & $\begin{array}{c}0.0121^{* * *} \\
(0.0020)\end{array}$ & $\begin{array}{c}0.0144 * * * \\
(0.0046)\end{array}$ & $\begin{array}{c}0.0128 * * * \\
(0.0043)\end{array}$ & $\begin{array}{c}0.0143 * * * \\
(0.0047)\end{array}$ \\
\hline Economic Crisis & & $\begin{array}{c}-0.0477 * * * \\
(0.0041)\end{array}$ & $\begin{array}{c}-0.0234^{* *} \\
(0.0092)\end{array}$ & $\begin{array}{c}-0.0168 * * \\
(0.0080)\end{array}$ & $\begin{array}{c}-0.0244 * * \\
(0.0112)\end{array}$ \\
\hline \multicolumn{6}{|l|}{ Homicides } \\
\hline Unemployment Rate & $\begin{array}{c}-0.0142^{* *} \\
(0.0056)\end{array}$ & $\begin{array}{c}-0.0057 * \\
(0.0032)\end{array}$ & $\begin{array}{l}-0.0099 \\
(0.0068)\end{array}$ & $\begin{array}{c}-0.0116 * \\
(0.0063)\end{array}$ & $\begin{array}{c}-0.0125^{*} \\
(0.0071)\end{array}$ \\
\hline Economic Crisis & & $\begin{array}{c}0.0027 \\
(0.0126)\end{array}$ & $\begin{array}{c}-0.0324 * \\
(0.0190)\end{array}$ & $\begin{array}{l}-0.0304 \\
(0.0199)\end{array}$ & $\begin{array}{l}-0.0145 \\
(0.0226)\end{array}$ \\
\hline Crisis Variable & None & $\begin{array}{c}\text { Severe } \\
\text { Recession }\end{array}$ & Crisis 1 & Crisis 2 & Crisis 3 \\
\hline
\end{tabular}


Note: See note on Table 7. Data are for 1,938 state-year observations, and are the regressions are weighted by state average populations. Models also include location dummy variables, location-specific linear time trends and controls for the share of the state population who are: female, black, other nonwhite, and aged $<1,1-19,45-54,55-64,65-74,75-84$ and $\geq 85$ years old. Year dummy variables are also controlled for, except in model (2). The Severe Recession and Crisis 1 through Crisis 3 variables are described in Table 4 and the note to Table 6. ${ }^{* * *} \mathrm{p}<0.01,{ }^{* *} \mathrm{p}<0.05,{ }^{*} \mathrm{p}<0.1$. 
Figure 1: Standardized Detrended Unemployment and Mortality Rates

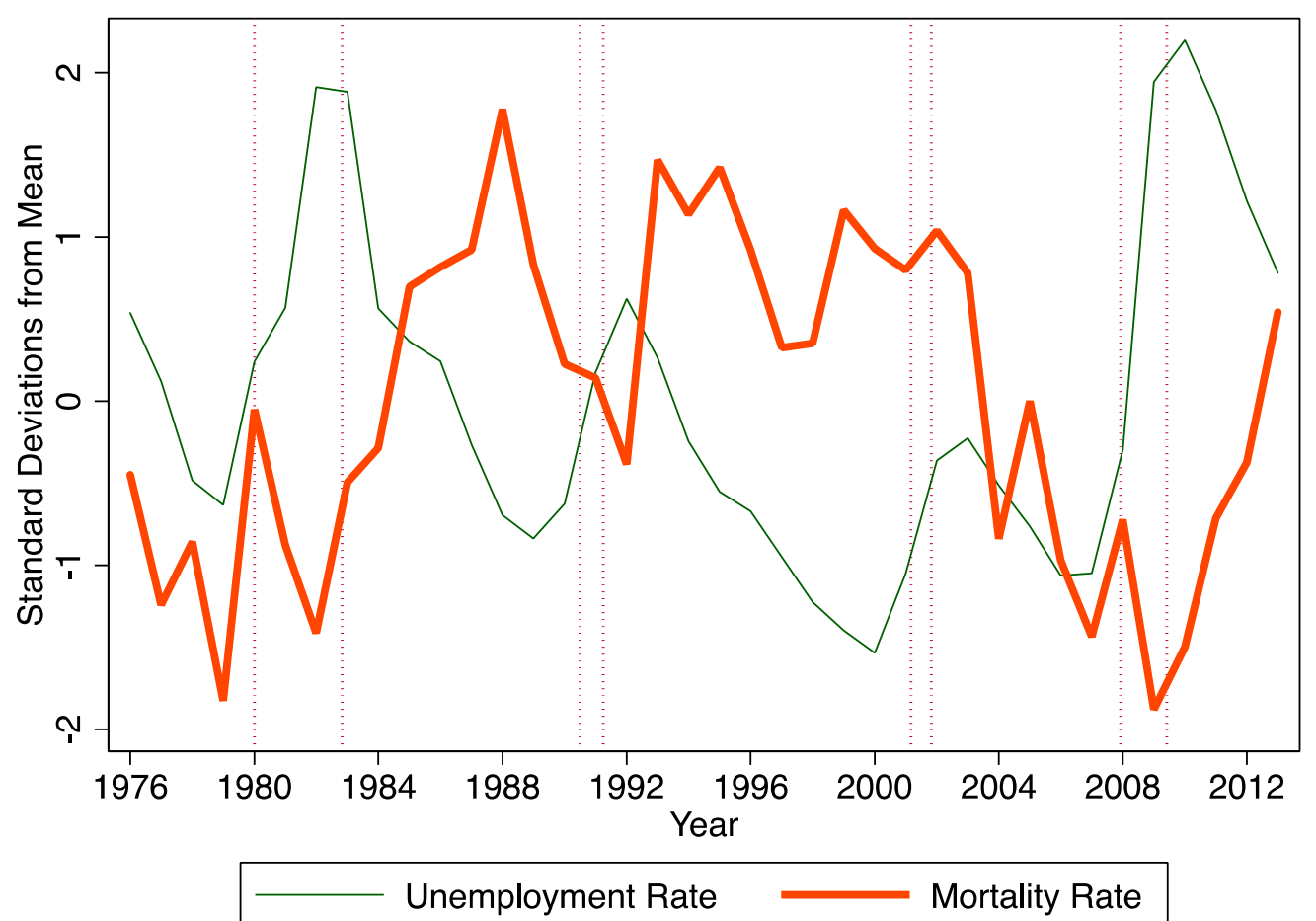

Note: Figure shows national unemployment and mortality rates that have been detrended (with a linear trend) and standardized to have mean of zero and standard deviation of one. 
Figure 2: Total Mortality Estimates, 15-Year Analysis Windows

Fig. 2A: State-Level Estimates

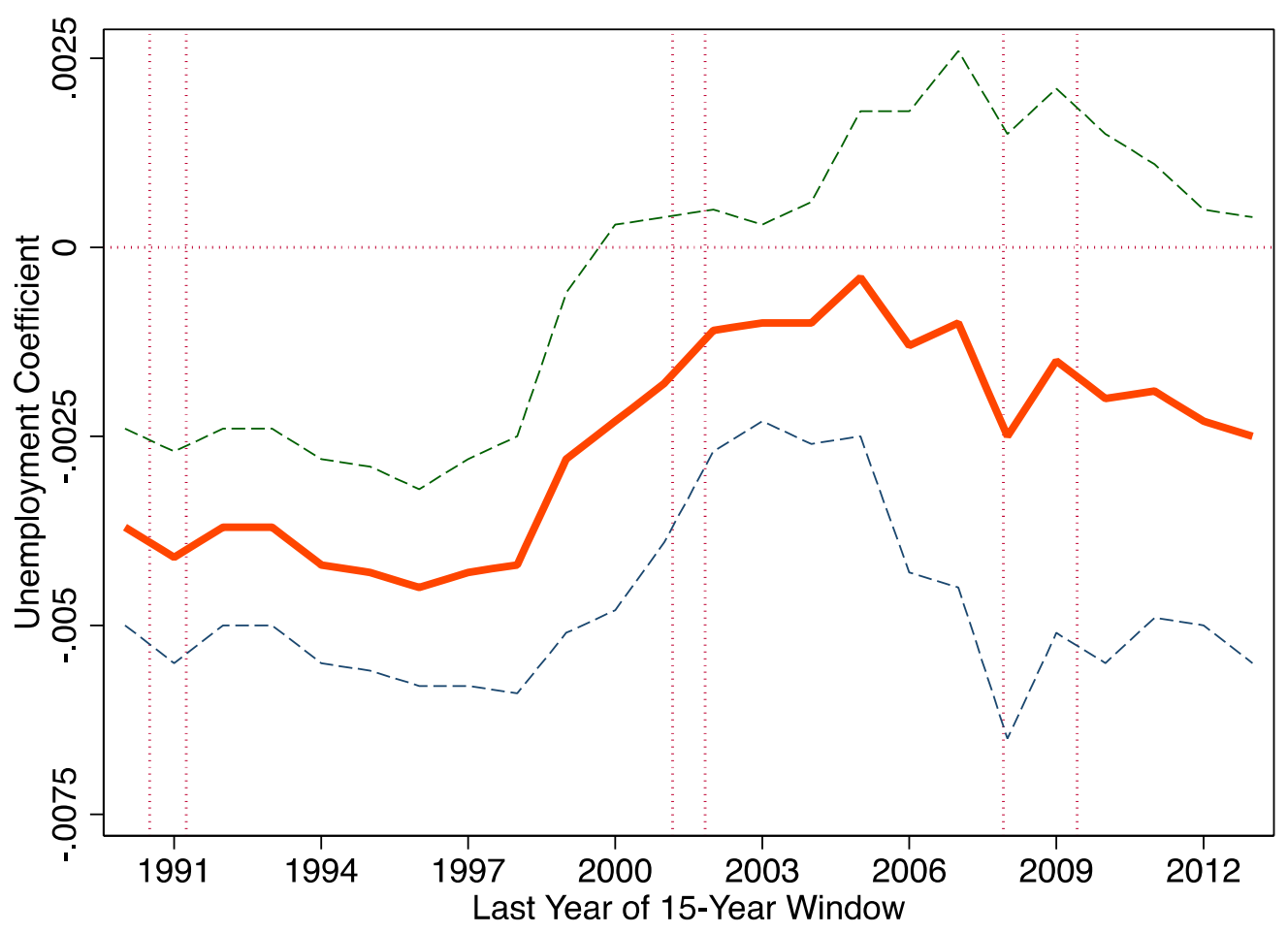

Fig. 2B: States vs. “Large” Counties

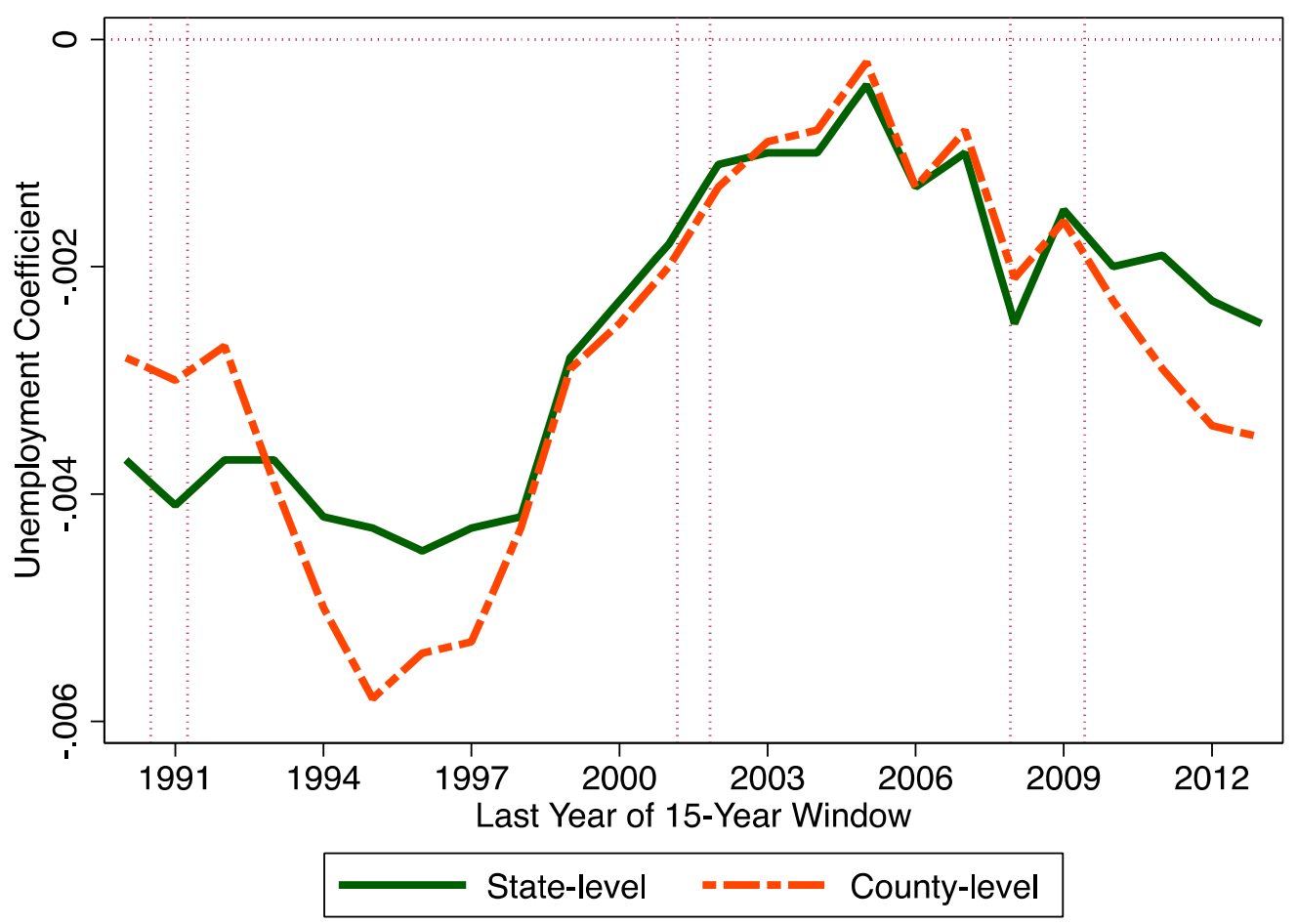


Note: Figure shows unemployment rate coefficient using 15-Year analysis windows and population-weighted data. Dashed lines show 95 percent confidence intervals. Vertical dotted vertical lines show recession periods. "Large" counties refer to those averaging more than 25,000 persons over the 1976-2013 analysis period. 
Figure 3: Disease and External Mortality Estimates, 15-Year Analysis Windows

Fig 3A: Disease Mortality

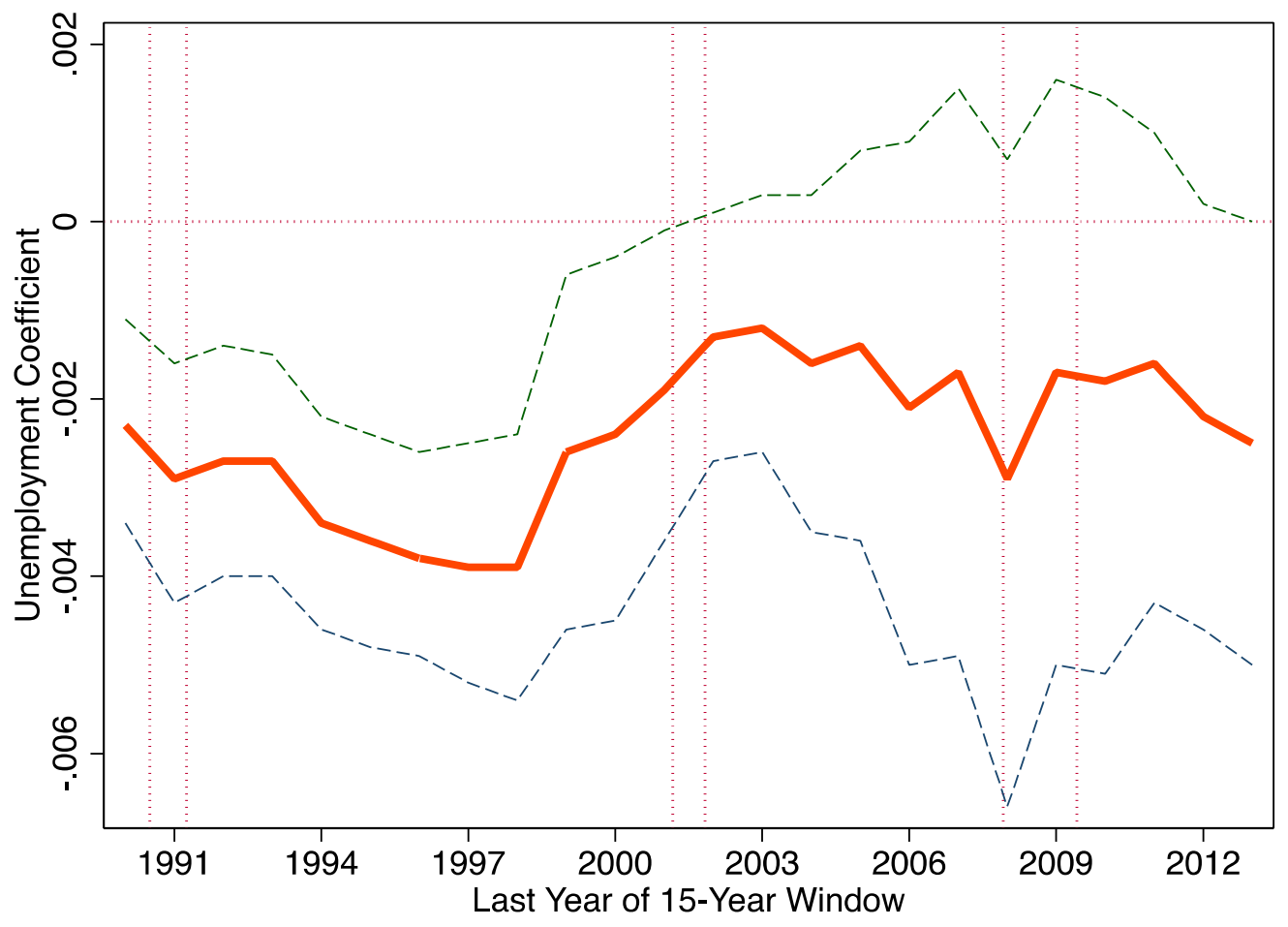

Fig 3B: External Cause Mortality

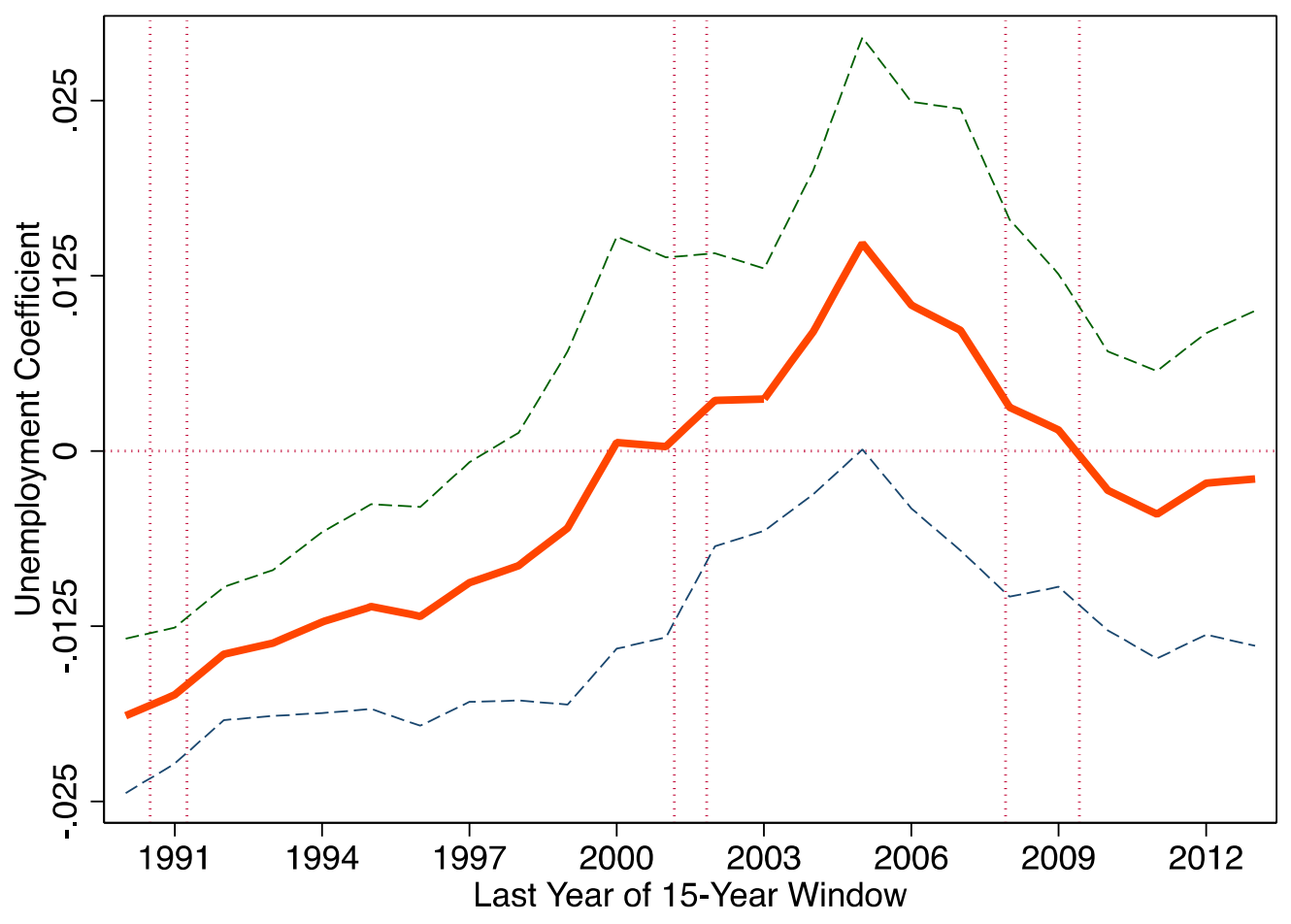


Note: Figure shows unemployment rate coefficient from models using 15-year analysis windows and population weighted data for the 50 states plus the District of Columbia $(n=1,938)$. The regressions also control for state and year dummy variables, state-specific linear time trends, and controls for the share of the county population who are: female, black, other nonwhite, and aged $<1,1-19,45-54,55-64,65-74,75-84$ and $\geq 85$ years old. Dashed lines show 95 percent confidence intervals. Vertical dotted vertical lines show recession periods. 
Appendix

Table A.1: Definitions of Specific Causes of Mortality

\begin{tabular}{|c|c|c|c|}
\hline Description & $\begin{array}{c}\text { ICD-8 } \\
(1976-1978)\end{array}$ & $\begin{array}{c}\text { ICD-9 } \\
(1979-1998)\end{array}$ & $\begin{array}{c}\text { ICD-10 } \\
(1999-2013)\end{array}$ \\
\hline Diseases & $000-796$ & 000-799 & A00-Q99 \\
\hline Cardiovascular Disease (CVD) & $390-448$ & $390-448$ & I00-I78 \\
\hline Malignant Neoplasms (Cancer) & $140-209$ & $140-208$ & C00-C97 \\
\hline Other Disease & $\begin{array}{l}000-136,210- \\
389,450-796\end{array}$ & $\begin{array}{l}000-136,210- \\
389,450-799\end{array}$ & $\begin{array}{c}\text { A00-B99, D00- } \\
\text { G99, J00-Q99 }\end{array}$ \\
\hline External Causes & 800-999 & $800-978$ & V01-Y89 \\
\hline Transport Accidents & $\begin{array}{c}\text { 800-848, 940- } \\
941\end{array}$ & $\begin{array}{c}800-848,929.0 \\
929.1\end{array}$ & V02-V99, Y85 \\
\hline Other Accidents & $\begin{array}{c}\text { 850-939, 942- } \\
949\end{array}$ & $\begin{array}{c}850-928,929.2- \\
949\end{array}$ & W00-X59, Y86 \\
\hline Suicide (Intentional Self-Harm) & $950-959$ & $950-959$ & X60-X84, Y87.0 \\
\hline Homicide/Legal Intervention & $960-978$ & $960-978$ & $\begin{array}{c}\text { X85-Y09, } \\
\text { Y87.1, Y35, } \\
\text { Y89.0 }\end{array}$ \\
\hline
\end{tabular}


Table A.2: Descriptive Statistics for Selected Analysis Variables

\begin{tabular}{|c|c|c|c|c|c|c|}
\hline \multirow[t]{2}{*}{ Variable } & \multicolumn{2}{|c|}{ State Sample } & \multicolumn{2}{|c|}{ County Sample } & \multicolumn{2}{|c|}{$\begin{array}{l}\text { Large County } \\
\text { Sample }\end{array}$} \\
\hline & Mean & SE & Mean & SE & Mean & SE \\
\hline \multicolumn{7}{|l|}{ Mortality Rates } \\
\hline All Deaths & 846.5 & 2.7 & 847.6 & 0.6 & 829.9 & 0.9 \\
\hline All Diseases & 785.9 & 2.6 & 787.1 & 0.6 & 771.0 & 0.8 \\
\hline Cardiovascular Disease (CVD) & 343.6 & 1.9 & 343.6 & 0.4 & 334.8 & 0.5 \\
\hline Malignant Neoplasms (Cancer) & 191.7 & 0.7 & 192.0 & 0.1 & 189.1 & 0.2 \\
\hline Other Diseases & 250.7 & 1.3 & 251.5 & 0.2 & 247.1 & 0.3 \\
\hline External Causes & 60.1 & 0.3 & 60.1 & 0.1 & 58.5 & 0.1 \\
\hline Transport Accidents & 18.0 & 0.1 & 18.0 & $3.1 \mathrm{E}-2$ & 17.0 & $3.7 \mathrm{E}-2$ \\
\hline Non-Transport Accidents & 21.5 & 0.1 & 21.6 & $3.0 \mathrm{E}-2$ & 20.9 & $3.8 \mathrm{E}-2$ \\
\hline Suicide & 11.9 & 0.1 & 11.9 & $1.6 \mathrm{E}-2$ & 11.7 & $1.9 \mathrm{E}-2$ \\
\hline Homicide/Legal Intervention & 7.7 & 0.1 & 7.7 & $2.1 \mathrm{E}-2$ & 7.8 & $3.0 \mathrm{E}-2$ \\
\hline \multicolumn{7}{|l|}{ State/County Characteristics } \\
\hline State Unemployment Rate (\%) & 6.5 & $4.7 \mathrm{E}-2$ & 6.5 & $6.0 \mathrm{E}-3$ & 6.5 & 8.7 E-3 \\
\hline$\%$ Female & 51.1 & $1.6 \mathrm{E}-2$ & 51.1 & $3.8 \mathrm{E}-3$ & 51.1 & $5.0 \mathrm{E}-3$ \\
\hline$\%$ Black & 12.7 & 0.2 & 12.7 & $3.8 \mathrm{E}-2$ & 13.0 & 0.1 \\
\hline \% Other Nonwhite & 4.7 & 0.1 & 4.6 & $1.9 \mathrm{E}-2$ & 4.8 & $2.7 \mathrm{E}-2$ \\
\hline$\%<1$ Year Old & 1.4 & 4.3 E-3 & 1.4 & $7.5 \mathrm{E}-4$ & 1.4 & $1.1 \mathrm{E}-3$ \\
\hline \% 1-19 Years Old & 27.5 & 0.1 & 27.4 & $1.0 \mathrm{E}-2$ & 27.4 & $1.4 \mathrm{E}-2$ \\
\hline \% 45-54 Years Old & 12.2 & $4.7 \mathrm{E}-2$ & 12.2 & $6.6 \mathrm{E}-3$ & 12.2 & $1.0 \mathrm{E}-2$ \\
\hline \% 55-64 Years Old & 9.6 & $3.5 \mathrm{E}-2$ & 9.6 & $5.8 \mathrm{E}-3$ & 9.5 & 8.1 E-3 \\
\hline$\%$ 65-74 Years Old & 6.9 & $2.4 \mathrm{E}-2$ & 6.9 & $5.6 \mathrm{E}-3$ & 6.8 & $7.8 \mathrm{E}-3$ \\
\hline \% 75-84 Years Old & 4.1 & $1.8 \mathrm{E}-2$ & 4.1 & 3.9 E-3 & 4.0 & $5.4 \mathrm{E}-3$ \\
\hline$\% \geq 85$ Year Olds & 1.4 & $9.3 \mathrm{E}-2$ & 1.4 & $1.7 \mathrm{E}-3$ & 1.4 & 2.3 E-3 \\
\hline Sample Size & \multicolumn{2}{|c|}{1,938} & \multicolumn{2}{|c|}{118,414} & \multicolumn{2}{|c|}{57,097} \\
\hline
\end{tabular}

Note: Data cover the period 1976-2013 and are for the 50 states plus the District of Columbia $(\mathrm{n}=1,938)$ in the state sample, for all 3,142 counties $(\mathrm{n}=118,326)$ in the county sample, and for the $1,515(n=57,097)$ with a population size averaging more than 25,000 persons over the entire period in the large county sample. Mortality rates are per 100,000 population. Observations are weighted by location-specific populations.

Data Sources. Mortality rates: CDC Compressed Mortality Files (http://www.cdc.gov/nchs/data_access/cmf.htm); unemployment rates: DOL Local Area Unemployment Statistics (LAUS) database (http://www.bls.gov/lau/data.htm); age, sex and racespecific population shares: Surveillance, Epidemiology, and End Results Program (http://seer.cancer.gov/popdata/). 
Table A.3: Cause-Specific Mortality Regressions with Separate Estimates for Early and Late Severe National Recessions

\begin{tabular}{|c|c|c|c|c|c|}
\hline Regressors & All Diseases & $\begin{array}{c}\text { Cardiovascular } \\
\text { Disease }\end{array}$ & Cancer & Other Diseases & \\
\hline Unemployment Rate & $\begin{array}{c}-0.0019 * * * \\
(0.0004)\end{array}$ & $\begin{array}{c}-0.0034 * * * \\
(0.0006)\end{array}$ & $\begin{array}{c}0.0015 * * * \\
(0.0004)\end{array}$ & $\begin{array}{c}-0.0029 * * * \\
(0.0008)\end{array}$ & \\
\hline Severe Recession: 1980-83 & $\begin{array}{l}-0.0030 \\
(0.0028)\end{array}$ & $\begin{array}{c}0.0245 * * * \\
(0.0034)\end{array}$ & $\begin{array}{c}-0.0098 * * * \\
(0.0024)\end{array}$ & $\begin{array}{c}-0.0423^{* * * *} \\
(0.0066)\end{array}$ & \\
\hline \multirow[t]{2}{*}{ Great Recession: 2008-10 } & $\begin{array}{c}-0.0063 * * * \\
(0.0013) \\
\end{array}$ & $\begin{array}{c}-0.0201^{* * *} \\
(0.0033)\end{array}$ & $\begin{array}{c}0.0011 \\
(0.0018) \\
\end{array}$ & $\begin{array}{c}0.0062 * * \\
(0.0029) \\
\end{array}$ & \\
\hline & $\begin{array}{l}\text { All External } \\
\text { Causes }\end{array}$ & $\begin{array}{l}\text { Transport } \\
\text { Accidents }\end{array}$ & Other Accidents & Suicides & Homicides \\
\hline Unemployment Rate & $\begin{array}{c}-0.0085 * * * \\
(0.0014)\end{array}$ & $\begin{array}{c}-0.0311^{* * *} \\
(0.0015)\end{array}$ & $\begin{array}{c}-0.0063 * * \\
(0.0027)\end{array}$ & $\begin{array}{c}0.0122^{* * *} \\
(0.0018)\end{array}$ & $\begin{array}{l}-0.0057 * \\
(0.0032)\end{array}$ \\
\hline Severe Recession: 1980-83 & $\begin{array}{c}-0.0230 * * \\
(0.0100)\end{array}$ & $\begin{array}{c}0.0157 \\
(0.0154)\end{array}$ & $\begin{array}{l}-0.0127 \\
(0.0111)\end{array}$ & $\begin{array}{c}-0.0799 * * * \\
(0.0063)\end{array}$ & $\begin{array}{c}0.0087 \\
(0.0182)\end{array}$ \\
\hline Great Recession: 2008-10 & $\begin{array}{c}-0.0187 * * * \\
(0.0068)\end{array}$ & $\begin{array}{c}-0.0412 * * * \\
(0.0102)\end{array}$ & $\begin{array}{l}-0.0094 \\
(0.0077)\end{array}$ & $\begin{array}{l}-0.0076 \\
(0.0069)\end{array}$ & $\begin{array}{l}-0.0047 \\
(0.0148)\end{array}$ \\
\hline
\end{tabular}

Note: Dependent variable is the natural log of the cause-specific mortality rate. First row of each panel displays coefficient on the state unemployment rate. Second and third rows show coefficients on indicators of the 1980-83 and 2008-2010 severe national recessions. corresponding to the years 1980-83 and 2008-10. Data are for 1,938 observations from the 50 states and District of Columbia fir 19762013. The regressions also include vectors of state dummy variables, state-specific linear time trends and controls for the share of the county population who are: female, black, other nonwhite, and aged $<1,1-19,45-54,55-64,65-74,75-84$ and $\geq 85$ years old. The data are weighted by state-specific average populations in columns (4) through (6). Robust standard errors, clustered at the state level, are in parentheses. ${ }^{* * *} \mathrm{p}<0.01, * * \mathrm{p}<0.05, * \mathrm{p}<0.1$. 
Figure A.1

Fig. A.1A: Disease Mortality - State vs. "Large” County Estimates

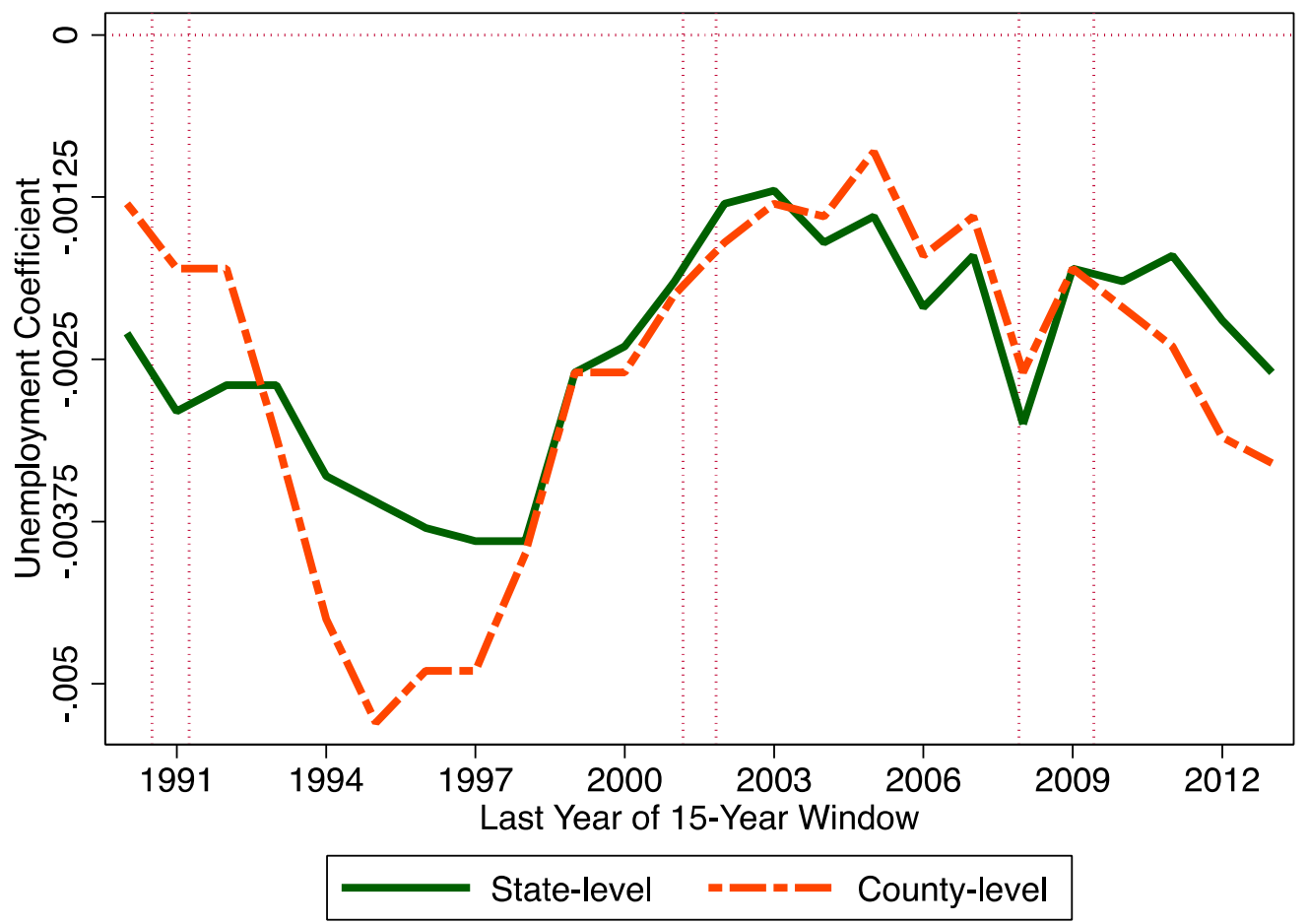

Figure A.1B: External Mortality - State vs. "Large” County Estimates

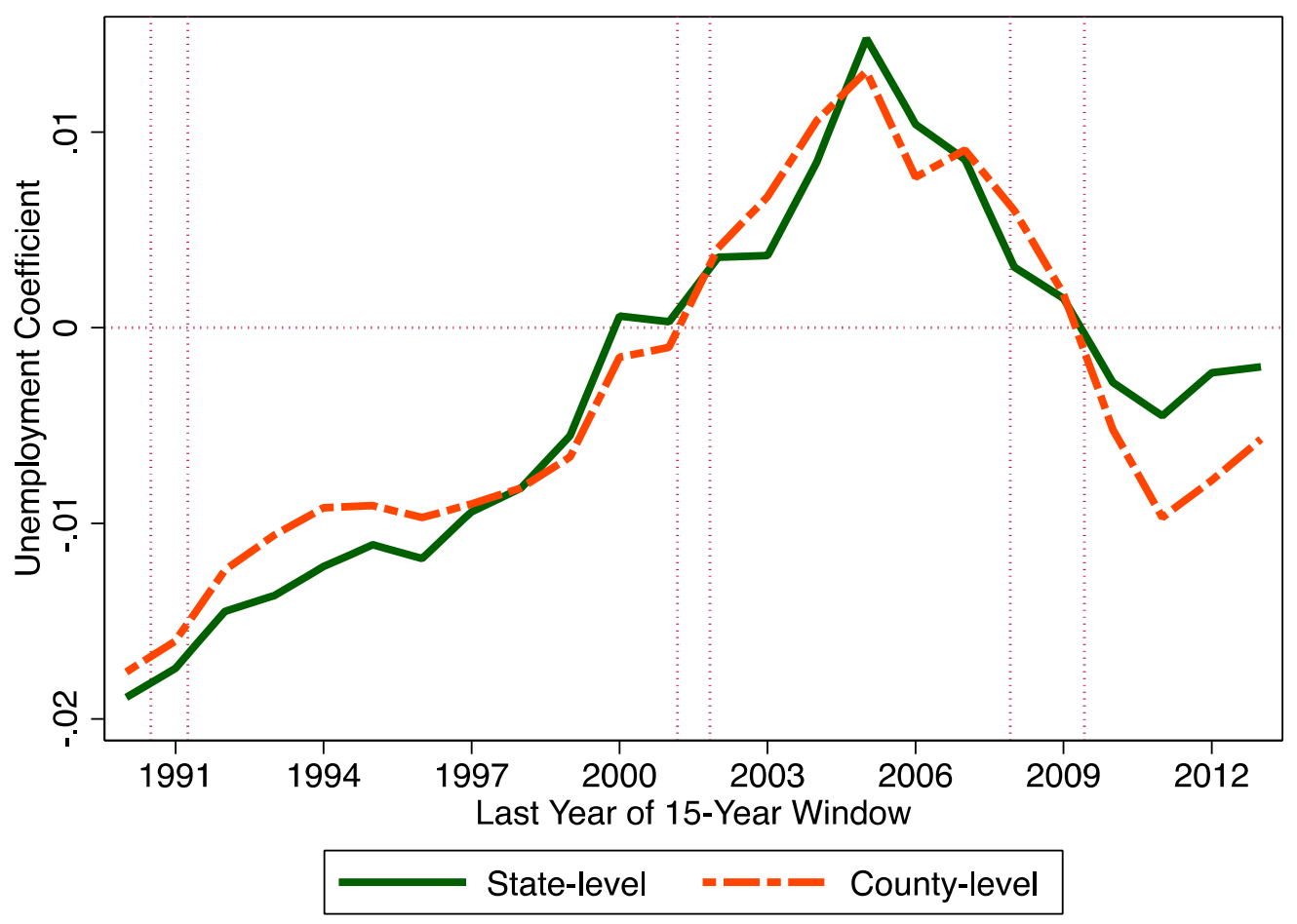


Note: See note on Figure 3. "Large" counties refer to those averaging more than 25,000 persons over the 1976-2013 analysis period. 